\title{
Evaluating the effect of modified atmosphere packaging on cheese characteristics: a review
}

\author{
Sadegh Khoshgozaran • Mohammad Hossein Azizi • \\ Niloofar Bagheripoor-Fallah
}

Received: 2 May 2011 /Revised: 22 June 2011 / Accepted: 23 June 2011 /

Published online: 11 August 2011

(C) INRA and Springer Science+Business Media B.V. 2011

\begin{abstract}
Dairy products are an important food group highly suggested by nutritionists. This food category is one of the most perishable, so extending their shelf life and keeping them fresh for a longer period of time is a matter of importance. Since consumers are now more aware of the possible hazards of preservatives, technologists and researchers have attempted to introduce novel preservative-free methods instead. One of these techniques is modified atmosphere packaging (MAP), which alters the natural gas surrounding the product in the package in order to delay deteriorative changes. In this paper, a review is made on the field of cheese MAP. Reported results revealed the potentiality of MAP in increasing cheese sensorial and microbial shelf life by carefully designing for an individual cheese.
\end{abstract}

\section{气调包装对干酪性质的影响}

摘要 乳制品作为重要的营养性食品, 容易发生腐败变质, 因此保证乳制品的品质和延长产品 的货架期具有重要的意义。由于消费者非常关注食品保藏过程中防腐剂带来的食品安全问 题, 因此些无防腐剂的新型保藏技术应运而生。气调包装是通过改变包装内产品周围环境 中气体组成的方式来达到延缓食品腐败的方法。本文对干酪气调包装的研究和应用领域进 行了综述, 并论述了气调包装对干酪货架期的延长以及货架期内干酪感官品质改变和微生物 变化。

Keywords Modified atmosphere packaging (MAP) $\cdot$ Cheese $\cdot$ Headspace gas composition evolution · Physicochemical properties · Microbiological analysis . Sensory evaluation

\footnotetext{
S. Khoshgozaran · M. H. Azizi $(\bowtie)$

Department of Food Science and Technology, Faculty of Agriculture,

Tarbiat Modares University, P.O. Box 14115-336, Tehran, Iran

e-mail: azizit_m@modares.ac.ir

N. Bagheripoor-Fallah

Department of Food Science and Technology,

National Nutrition and Food Technology Research Institute, Tehran, Iran
} 
关键词 气调包装·干酪·顶空气相色谱·物理化学特性·微生物分析·感官评价

\section{Introduction}

Increasing the shelf life of food using different preservative methods has always been a major concern of humankind. Preliminary attempts in this regard include sun drying during the summer and atmospheric freezing during the winter, as well as natural fermentation, which was innovated by ancient Asians (Ooraikul and Stiles 1991). Today, several preservation techniques are available to extend the shelf storage of food products, among which packaging is the most promising. The packaging process undertakes several basic roles such as preventing microbial and chemical quality deterioration and enhancing the handling and marketing for packaged products. Now, food packaging not only targets convenience and protection properties but also presents many other applications (Han 2005).

Over the past two decades, modified atmosphere packaging (MAP) has attracted the attention of researchers as a practical technique for retaining the quality of various food products in addition to meeting the increased demand of customers for fresh and preservative-free food (Piergiovanni et al. 1993; Phillips 1999; Floros and Nielsen 2000). Furthermore, it has a number of advantages, such as quality retention of fresh products, image improvement of the product, extension of shelf life, and minimum use of additives and preservatives (Garabal et al. 2010). The atmosphere inside a package can be modified by either passive or active methods. In passive MAP, the rate of change and the final gas composition in the package depend on both the packed product and the permeability of the packaging material. This MAP technique has the main disadvantage that it may require a long storage period to achieve the optimal gas composition, which could be especially important for products with relatively short shelf life. This disadvantage can be overcome with the use of active modification of the atmosphere. Active MAP is usually accomplished by first creating a vacuum and then injecting the desired gas mixture in the package; in this case, the desired atmosphere is directly achieved at the beginning of storage and remains unchanged, provided the right packaging material is used and there is no leakage. The disadvantage of active MAP over passive MAP is the higher cost in equipment and gases (Rodriguez-Aguilera and Oliveira 2009).

MAP techniques are now used for a wide variety of products involving cakes, fresh filled pasta, potato crisps, fruits and vegetables, and meat products (Jayas and Jeyamkondan 2002; Silva et al. 2004; Guynot et al. 2004; Zardetto 2005; McMillin 2008). This paper tries to review the application of MAP in cheese by including fresh, whey, soft, semi-hard, and hard cheese along with other types which are produced and consumed all around the world.

\section{Overview of basic works and important considerations in cheese MAP}

Studies on the possible effectiveness of MAP started with the emergence of two works: First, Zimmerman and Kester (1960) found that hermetically sealed containers, vacuum packaging, and packaging under inert gases are successful in 
delaying surface spoilage caused by aerobic organisms which were inoculated with less than ten causative organisms per gram onto Cottage cheese and were stored at $10{ }^{\circ} \mathrm{C}$. Second, Tsantilis and Kosikowski (1960) studied the effect of vacuum and $\mathrm{N}_{2}$ or $\mathrm{CO}_{2}$ atmospheres on the shelf life of creamed and uncreamed Cottage cheese, packed in aluminum at $5{ }^{\circ} \mathrm{C}$, reporting that $\mathrm{CO}_{2}$ significantly reduced yeast and mold counts and maintains fresh flavor even after a prolonged storage (even after 12 weeks).

Taylor et al. (1965) reported that $\mathrm{N}_{2}$ is insignificant in improving the shelf life of Cottage cheese. Krcal (1970) demonstrated depression in microbial damages of Cottage cheese by $\mathrm{CO}_{2}$ and $\mathrm{N}_{2}$ at ambient temperature, whereas the $\mathrm{CO}_{2}$ flushing atmosphere was preferable. However, Scott and Smith (1971), who evaluated the shelf life quality of Cottage cheese (based on taste panel scoring and bacterial counts of the top centimeter of samples stored at $3-4{ }^{\circ} \mathrm{C}$ for $10-12$ days in special all-glass containers with purified carbon dioxide, nitrogen, and air atmospheres), indicated that packaging Cottage cheese under neither $\mathrm{CO}_{2}$ nor $\mathrm{N}_{2}$ flushing could greatly improve the shelf life of samples at $3{ }^{\circ} \mathrm{C}$. Furthermore, they proposed that $\mathrm{CO}_{2}$ flushing could change the flavor as an acid or tart cheese, which is treated differently (as an advantage or disadvantage) with respect to local preferences. Kosikowski and Brown (1973) conducted a study evaluating the influence of carbon dioxide and nitrogen on the shelf life of creamed Cottage cheese ( $\mathrm{pH} 4.5)$ sealed in commercial thermoplastic containers following air evacuation and $\mathrm{CO}_{2}$ or $\mathrm{N}_{2}$ flushing and stored at $4{ }^{\circ} \mathrm{C}$. The authors obtained excellent qualities under $\mathrm{CO}_{2}$ or $\mathrm{N}_{2}$ atmospheres for 45 days at the refrigeration temperature. In addition, they pointed out that the use of carbon dioxide presents flavor-related problems, such as a fizzy flavor, suggesting that the alternation in the $\mathrm{CO}_{2} / \mathrm{N}_{2}$ ratio in favor of nitrogen can eliminate the undesired flavor while maintaining the freshness of flavor and control the microbial population.

The effectiveness of modified atmosphere packaging in extending the shelf life of dairy products, especially cheese, has been confirmed by further studies, and different gas compositions have been suggested for MAP packaging of cheese. Romani et al. (1999) evaluated storage stability of 24-month-old portioned-packed Parmigiano Reggiano cheese, packed in nylon/polyethylene bags and stored for 3 months at $4{ }^{\circ} \mathrm{C}$. The results did not show substantial changes in the quality of differently packed products, although samples packed in $100 \% \mathrm{~N}_{2}$ atmosphere showed flavor profiles quite distant from that of the freshly cut, unpacked cheese. Taniwaki et al. (2001) investigated the growth of fungi and mycotoxin production on commercial sliced cheddar cheese under modified atmospheres. Eight fungal species were incubated under conditions of decreasing concentrations of $\mathrm{O}_{2}(5 \%$ to $<0.5 \%)$ and increasing concentrations of $\mathrm{CO}_{2}(20-40 \%)$. The authors observed a reduction in the growth of fungi by $20-80 \%$ depending on species and found that the formation of aflatoxins $\mathrm{B}_{1}$ and $\mathrm{B}_{2}$, roquerfortin $\mathrm{C}$, and cyclopiazonic acid were greatly decreased.

Mortensen et al. (2003) studied the impact of different MAP atmosphere on the photo-oxidation of sliced Havarti cheese and observed that for cheeses exposed to light and packed with $0.6 \%$ residual oxygen, photo-oxidation increased considerably in comparison with the ones packed with $0.01 \%$ residual oxygen.

Dankow et al. (2006) studied the effect of a packaging system on the quality and shelf life of the Rokpol-type mold cheese made from goat milk. The samples were 
packed in aluminum foil and modified atmospheres $\left(100 \% \mathrm{~N}_{2}, 30 \% \mathrm{CO}_{2} / 70 \% \mathrm{~N}_{2}\right.$, $50 \% \mathrm{CO}_{2} / 50 \% \mathrm{~N}_{2}, 70 \% \mathrm{CO}_{2} / 30 \% \mathrm{~N}_{2}, 100 \% \mathrm{CO}_{2}, 30 \% \mathrm{CO}_{2} / 60 \% \mathrm{~N}_{2} / 10 \% \mathrm{O}_{2}, 70 \%$ $\mathrm{CO}_{2} / 20 \% \mathrm{~N}_{2} / 10 \% \mathrm{O}_{2}$ using oriented polyethylene polyamide as the packaging material) as well as in vacuum. The authors observed proliferation of the coli type of bacteria in the experimented cheese in aluminum foil, whereas the population of the coli group remained constant over the storage time in other samples, irrespective of the type of applied gas mixture.

Alam and Goyal (2007) evaluated the shelf life of Mozzarella cheese under different atmospheres (air, vacuum, $100 \% \mathrm{CO}_{2}, 100 \% \mathrm{~N}_{2}$, and $50 \% \mathrm{~N}_{2} / 50 \% \mathrm{CO}_{2}$ ) packed in high-barrier bags and stored at -10 to $-15{ }^{\circ} \mathrm{C}$. The authors reported that Mozzarella cheese under MAP conditions compared with those in conventional air package had a significant increase in their shelf life (14-16, 90, 75, and 65 days under air, $100 \% \mathrm{CO}_{2}, 50 \% \mathrm{~N}_{2} / 50 \% \mathrm{CO}_{2}$, and $100 \% \mathrm{~N}_{2}$, respectively).

The shelf life of MAP-packaged cheese is affected by some important parameters including the use of starter cultures in cheese production, type of cheese, initial microbial contamination and storage conditions (Floros and Nielsen 2000), composition of the gas atmosphere inside the package, and types of applied packaging materials (Hotchkiss 1988). Table 1 summarizes references on MAP of cheeses.

MAP design is composed of handpicking the film type and size of packaging for each product (Farber et al. 2003). Therefore, different types of packaging concepts are required for various types of cheeses. Permeability to $\mathrm{O}_{2}, \mathrm{CO}_{2}$, and water vapor transmission rates for packaging films are among the most essential factors in determining the package atmosphere composition, which may influence the product's deterioration rate (Mullan and McDowell 2003; Church 1994). The final decision on packaging film should be made based on vast assessments and in collaboration with the packaging suppliers (Sandhya 2010). Important properties of packaging materials, commonly hired for cheese packaging, are presented in Table 2.

\section{Characteristics of cheese in MAP}

\subsection{Headspace gas composition evolution}

There are three main gases used in MAP — nitrogen, oxygen, and carbon dioxidethe role and importance of each of which are related to its properties (Mullan and McDowell 2003). Other investigated gases include nitrous and nitric oxides, sulfur dioxide, ethylene, ethanol, chlorine, ozone, propylene oxide, carbon monoxide, and argon. These gases failed to enter into commercial applications due to safety, regulatory, and cost considerations (Church 1994; Sandhya 2010).

A review of the related literature showed different results for the nitrogen, oxygen, and carbon dioxide concentration changes over the storage time (Table 3 ). The possible reasons for the recorded changes are as follows:

$\mathrm{CO}_{2}$ changes

- Remaining constant: The equilibrium between $\mathrm{CO}_{2}$ dissolution in the cheese mass and $\mathrm{CO}_{2}$ production through aerobic microbial metabolism (Eliot et al. 1998) 
Table 1 References on modified atmosphere packaging of cheese

\begin{tabular}{|c|c|c|c|c|}
\hline Reference & Cheese type & Packaging film & MAP conditions studied $(\%)$ & Optimal MAP (\%) \\
\hline Garabal et al. (2010) & $\begin{array}{l}\text { San Simon da Costa } \\
\text { (smoked semi-hard } \\
\text { cow's milk cheese) }\end{array}$ & $\begin{array}{l}\text { Multilayer polyester polyvinyl } \\
\text { chloride and polyethylene }\end{array}$ & $\mathrm{VP}, 100 \mathrm{~N}_{2}, 20 \mathrm{CO}_{2} / 80 \mathrm{~N}_{2}$ and $50 \mathrm{CO}_{2} / 50 \mathrm{~N}_{2}$ & $\geq 50 \mathrm{CO}_{2}$ \\
\hline Taniwaki et al. (2001) & $\begin{array}{l}\text { Commercial sliced } \\
\text { cheddar }\end{array}$ & $\begin{array}{l}\text { Polypropylene/ethylene vinyl } \\
\text { alcohol/polypropylene }\end{array}$ & $\begin{array}{l}20 \mathrm{CO}_{2} /<0.5 \% \mathrm{O}_{2}, 20 \mathrm{CO}_{2} / 1 \mathrm{O}_{2}, 20 \mathrm{CO}_{2} / 5 \mathrm{O}_{2} \\
\quad 40 \mathrm{CO}_{2} /<0.5 \mathrm{O}_{2}, 40 \mathrm{CO}_{2} / 1 \mathrm{O}_{2} \text { and } 40 \mathrm{CO}_{2} / 5 \mathrm{O}_{2}\end{array}$ & Atmospheres with $\mathrm{O}_{2}<0.5 \%$ \\
\hline Eliot et al. (1998) & Mozzarella & $\begin{array}{l}\text { Multilayer of polyolefins with } \\
\text { polyvinylidene chloride }\end{array}$ & $\begin{array}{l}100 \mathrm{~N}_{2}, 10 \mathrm{CO}_{2} / 90 \mathrm{~N}_{2}, 25 \mathrm{CO}_{2} / 75 \mathrm{~N}_{2}, 50 \mathrm{CO}_{2} / 50 \\
\mathrm{~N}_{2}, 75 \mathrm{CO}_{2} / 25 \mathrm{~N}_{2} \text { and } 100 \mathrm{CO}_{2}\end{array}$ & $75 \mathrm{CO}_{2} / 25 \mathrm{~N}_{2}$ \\
\hline Alves et al. (1996) & Mozzarella & $\begin{array}{l}\text { Thermoformed transparent laminate } \\
\text { of polyamide and polyethylene }\end{array}$ & $100 \mathrm{~N}_{2}, 100 \mathrm{CO}_{2}$ and $50 \mathrm{CO}_{2} / 50 \mathrm{~N}_{2}$ & $100 \mathrm{CO}_{2}$ \\
\hline Juric et al. (2003) & $\begin{array}{l}\text { Rindless semi-hard } \\
\text { Samøs }\end{array}$ & $\begin{array}{l}\text { Thermoformed transparent laminate } \\
\text { of polyamide and polyethylene }\end{array}$ & $100 \mathrm{~N}_{2}, 20 \mathrm{CO}_{2} / 80 \mathrm{~N}_{2}$ and $100 \mathrm{CO}_{2}$ & $100 \mathrm{~N}_{2}$ and $20 \mathrm{CO}_{2} / 80 \mathrm{~N}_{2}$ \\
\hline Maniar et al. (1994) & Cottage & $\begin{array}{l}\text { Low-density polyethylene/ } \\
\text { biaxially } \\
\text { oriented nylon/layer of } \\
\text { polyvinylidene chloride }\end{array}$ & $100 \mathrm{CO}_{2}, 75 \mathrm{CO}_{2} / 25 \mathrm{~N}_{2}$ and $100 \mathrm{~N}_{2}$ & $\geq 75 \mathrm{CO}_{2}$ \\
\hline $\begin{array}{l}\text { Mannheim and Soffer } \\
\text { (1996) }\end{array}$ & Cottage & - & $100 \mathrm{CO}_{2}$ & $100 \mathrm{CO}_{2}$ \\
\hline Trobetas et al. (2008) & Graviera (hard cheese) & $\begin{array}{l}\text { Low-density polyethylene/ } \\
\text { polyamide/low-density } \\
\text { polyethylene (LDPE/PA/LDPE) }\end{array}$ & $100 \mathrm{CO}_{2}, 50 \mathrm{CO}_{2} / 50 \mathrm{~N}_{2}$ and $100 \mathrm{~N}_{2}$ & $50 \mathrm{CO}_{2} / 50 \mathrm{~N}_{2}$ and $100 \mathrm{~N}_{2}$ \\
\hline Kristensen et al. (2000) & Havarti & Polyester & $25 \mathrm{CO}_{2} / 75 \mathrm{~N}_{2}$ & \\
\hline $\begin{array}{l}\text { Pintado and Malcata } \\
\text { (2000) }\end{array}$ & Requeijão & - & $100 \mathrm{CO}_{2}$ and $50 \mathrm{CO}_{2} / 50 \mathrm{~N}_{2}$ & $100 \mathrm{CO}_{2}$ \\
\hline Olarte et al. (2002) & $\begin{array}{l}\text { Cameros (fresh goat } \\
\text { cheese) }\end{array}$ & - & $20 \mathrm{CO}_{2} / 80 \mathrm{~N}_{2}, 40 \mathrm{CO}_{2} / 60 \mathrm{~N}_{2}$ and $100 \mathrm{CO}_{2}$ & $100 \mathrm{CO}_{2}$ \\
\hline $\begin{array}{l}\text { Papaioannou et al. } \\
\text { (2007) }\end{array}$ & Greek whey cheese & $\begin{array}{l}\text { Low-density polyethylene/ } \\
\text { polyamide/low-density } \\
\text { polyethylene (LDPE/PA/LDPE) }\end{array}$ & $\mathrm{VP}, 30 \mathrm{CO}_{2} / 70 \mathrm{~N}_{2}$ and $70 \mathrm{CO}_{2} / 30 \mathrm{~N}_{2}$ & $70 \mathrm{CO}_{2} / 30 \mathrm{~N}_{2}$ \\
\hline
\end{tabular}


Table 1 (continued)

\begin{tabular}{|c|c|c|c|c|}
\hline Reference & Cheese type & Packaging film & MAP conditions studied (\%) & Optimal MAP (\%) \\
\hline Dermiki et al. (2008) & $\begin{array}{l}\text { Myzithra Kalathaki } \\
\text { (whey cheese) }\end{array}$ & $\begin{array}{l}\text { Low-density polyethylene/ } \\
\text { polyamide/low-density } \\
\text { polyethylene (LDPE/PA/LDPE) }\end{array}$ & $20 \mathrm{CO}_{2} / 80 \mathrm{~N}_{2}, 40 \mathrm{CO}_{2} / 60 \mathrm{~N}_{2}$ and $60 \mathrm{CO}_{2} / 40 \mathrm{~N}_{2}$ & $40 \mathrm{CO}_{2} / 60 \mathrm{~N} 2$ and $60 \mathrm{CO}_{2} / 40 \mathrm{~N}_{2}$ \\
\hline $\begin{array}{l}\text { Gammariello et al. } \\
\text { (2009b) }\end{array}$ & Stracciatella & $\begin{array}{l}\text { Laminate of a polyamide (nylon) } \\
\text { and a polyolefin }\end{array}$ & $\begin{array}{l}\mathrm{VP}, 50 \mathrm{CO}_{2} / 50 \mathrm{~N}_{2}, 95 \mathrm{CO}_{2} / 5 \mathrm{~N}_{2}, 75 \mathrm{CO}_{2} / 25 \mathrm{~N}_{2} \\
\text { and } 30 \mathrm{CO}_{2} / 65 \mathrm{~N}_{2} / 5 \mathrm{O}_{2}\end{array}$ & $95 \mathrm{CO}_{2} / 5 \mathrm{~N} 2,50 \mathrm{CO}_{2} / 50 \mathrm{~N}_{2}$ \\
\hline Esmer et al. (2009) & Crottin de Chavignol & $\begin{array}{l}\text { Polyamide/low-density } \\
\text { polyethylene (PA/LDPE) }\end{array}$ & $\mathrm{VP}$ and $50 \mathrm{CO}_{2} / 50 \mathrm{~N}_{2}$ & $20 \mathrm{CO}_{2} / 80 \mathrm{~N}_{2}$ \\
\hline $\begin{array}{l}\text { Rodriguez-Aguilera } \\
\text { et al. (2011b) }\end{array}$ & Surface mold-ripened & Acrylic cylindrical container & $0 \mathrm{O}_{2} / 27 \pm 6 \mathrm{CO}_{2}$ and $2 \pm 1 \mathrm{O}_{2} / 19 \pm 2 \mathrm{CO}_{2}$ & $\begin{array}{l}\text { Low levels of } \mathrm{O}_{2}(1-3 \%) \text { and } \\
\text { relatively high levels of } \mathrm{CO}_{2} \\
(17-21 \%)\end{array}$ \\
\hline Favati et al. (2007) & Provolone & $\begin{array}{c}\text { Polyamide (PA) and } \\
\text { polyethylene (PE) }\end{array}$ & $\begin{array}{l}10 \mathrm{CO}_{2} / 90 \mathrm{~N}_{2}, 20 \mathrm{CO}_{2} / 80 \mathrm{~N}_{2}, 30 \mathrm{CO}_{2} / 70 \mathrm{~N}_{2} \text { and } \\
\quad 100 \mathrm{CO}_{2}\end{array}$ & $30 \mathrm{CO}_{2} / 70 \mathrm{~N}_{2}$ \\
\hline \multirow[t]{2}{*}{$\begin{array}{l}\text { Gammariello et al. } \\
\text { (2009a) }\end{array}$} & $\begin{array}{l}\text { Giuncata (Apulian } \\
\text { fresh cheeses) }\end{array}$ & \multirow[t]{2}{*}{$\begin{array}{l}\text { Laminate of a polyamide (nylon) } \\
\text { and a polyolefin }\end{array}$} & $\begin{array}{l}\mathrm{VP}, 50 \mathrm{CO}_{2} / 50 \mathrm{~N}_{2}, 90 \mathrm{CO}_{2} / 10 \mathrm{~N}_{2}, 75 \mathrm{CO}_{2} / 25 \mathrm{~N}_{2} \\
\text { and } 30 \mathrm{CO}_{2} / 65 \mathrm{~N}_{2} / 5 \mathrm{O}_{2}\end{array}$ & $75 \mathrm{CO}_{2} / 25 \mathrm{~N}_{2}$ \\
\hline & $\begin{array}{l}\text { Primosale (Apulian } \\
\text { fresh cheeses) }\end{array}$ & & $\mathrm{CO}_{2} / 10 \mathrm{~N}_{2}, 75 \mathrm{CO}_{2} / 25 \mathrm{~N}_{2}$ and $30 \mathrm{CO}_{2} / 65 \mathrm{~N}_{2} / 5 \mathrm{O}_{2}$ & $95 \mathrm{CO}_{2} / 5 \mathrm{~N}_{2}$ and $50 \mathrm{CO}_{2} / 50 \mathrm{~N}_{2}$ \\
\hline Temiz et al. (2009) & $\begin{array}{l}\text { Lor (Turkish whey } \\
\text { cheese) }\end{array}$ & Polyethylene & $\mathrm{VP}, 40 \mathrm{CO}_{2} / 60 \mathrm{~N}_{2}, 60 \mathrm{CO}_{2} / 40 \mathrm{~N}_{2}$ and $70 \mathrm{CO}_{2} / 30 \mathrm{~N}_{2}$ & $60 \mathrm{CO}_{2} / 40 \mathrm{~N}_{2}$ and $70 \mathrm{CO}_{2} / 30 \mathrm{~N}_{2}$ \\
\hline Temiz (2010) & Kashar & Polyethylene & & $40 \mathrm{CO}_{2} / 60 \mathrm{~N}_{2}$ and $100 \mathrm{CO}_{2}$ \\
\hline $\begin{array}{l}\text { Gonzalez-Fandos } \\
\text { et al. (2000) }\end{array}$ & Cameros & - & $\begin{array}{l}\mathrm{VP}, 50 \mathrm{CO}_{2} / 50 \mathrm{~N}_{2}, 20 \mathrm{CO}_{2} / 80 \mathrm{~N}_{2}, 40 \mathrm{CO}_{2} / 60 \mathrm{~N}_{2} \\
\text { and } 100 \mathrm{CO}_{2}\end{array}$ & $100 \mathrm{CO}_{2}$ \\
\hline $\begin{array}{l}\text { Del Nobile et al. } \\
\text { (2009) }\end{array}$ & Ricotta & $\begin{array}{l}\text { Nylon-based high-barrier } \\
\text { multilayer plastic bags }\end{array}$ & $50 \mathrm{CO}_{2} / 50 \mathrm{~N}_{2}, 70 \mathrm{CO}_{2} / 30 \mathrm{~N}_{2}$ and $95 \mathrm{CO}_{2} / 5 \mathrm{~N}_{2}$ & $95 \mathrm{CO}_{2} / 5 \mathrm{~N}_{2}$ \\
\hline
\end{tabular}

$V P$ vacuum packaging 
Table 2 Properties of packaging materials used for cheese

\begin{tabular}{|c|c|c|c|c|c|c|}
\hline Packaging material type & Structure & $\begin{array}{l}\text { Moisture } \\
\text { permeability }^{\text {a }}\end{array}$ & Oxygen permeability ${ }^{\mathrm{b}}$ & $\begin{array}{l}\text { Carbon dioxide } \\
\text { permeability }^{\mathrm{c}}\end{array}$ & $\begin{array}{l}\text { Nitrogen } \\
\text { permeability }^{\mathrm{d}}\end{array}$ & $\begin{array}{l}\text { Light } \\
\text { transmission }^{\mathrm{e}}\end{array}$ \\
\hline Low-density polyethylene, LDPE & $\begin{array}{l}\text { Ethylene units; density, 0.917- } \\
0.924\left({\left.\mathrm{~g} . ~ \mathrm{~cm}^{-3}\right)}^{-3}\right.\end{array}$ & $1-10$ or $10-50$ & $>1,000$ & $130-280$ & $1.9-3.1$ & 65 \\
\hline Polypropylene, PP & Propylene units & $1-10$ & $>1,000$ & 92 & 4.4 & 80 \\
\hline Ethylvinyl acetate, EVA & $\begin{array}{l}\text { Copolymerization of low-density } \\
\text { polyethylene and 1-20\% vinyl } \\
\text { acetate }\end{array}$ & $10-50$ & $>1,000$ & - & - & $55-75$ \\
\hline Polystyrene, PS & Styrene units & $>50$ & $>1,000$ & 105 & 7.8 & 92 \\
\hline Polyethylene terephthalate, PET & $\begin{array}{l}\text { Ethylenglycol and } \\
\text { dimethylterephthalate or } \\
\text { terephthalate acid }\end{array}$ & $10-50$ & $10-100$ or $100-1,000$ & 3.0 & $0.04-0.06$ & 88 \\
\hline Polyamide (nylon), PA & $\begin{array}{l}\text { Nylon 6: polymerization of } \\
\text { caprolactam }\end{array}$ & $10-50$ & $10-100$ when dry & $0.4-0.8$ & 0.95 & 88 \\
\hline $\begin{array}{l}\text { Polyvinylidene chloride, PVdC } \\
\text { (Saran) }\end{array}$ & Vinyliden units & $<1$ or $1-10$ & $1-10$ & 0.3 & 0.009 & 90 \\
\hline Ethylvinyl alcohol, EVOH & Ethylvinyl acetate and methanol & $10-50$ or $>50$ & $\begin{array}{l}1-10 \text { or below } 75 \% \\
\text { RH: }<1\end{array}$ & $\begin{array}{l}27 \mathrm{~mol} \% \text { ethylene: } \\
0.024 \text { and } 44 \mathrm{~mol} \% \\
\text { ethylene: } 0.012\end{array}$ & - & 90 \\
\hline
\end{tabular}

References: McMillin (2008), Mullan and McDowell (2003), and Church (1994)

${ }^{\mathrm{a}}$ Moisture permeability (g. $\mathrm{m}^{-2} \mathrm{day}^{-1}, 38{ }^{\circ} \mathrm{C}, 90 \% \mathrm{RH}$ )

${ }^{\mathrm{b}}$ Oxygen permeability $\left(\mathrm{mL} \cdot \mathrm{m}^{-2}\right.$.day ${ }^{-1} \cdot$ atm $\left.^{-1}, 20{ }^{\circ} \mathrm{C}, 0 \% \mathrm{RH}\right)$

${ }^{\mathrm{c}}$ Carbon dioxide permeability $\left(P \times 10^{11}\left[\mathrm{~mL}(\mathrm{STP}) \mathrm{cm} \cdot \mathrm{cm}^{-2} \cdot \mathrm{s}^{-1} \cdot(\mathrm{cm} \mathrm{Hg})^{-1}\right]\right.$ at $\left.25^{\circ} \mathrm{C}\right)$

${ }^{\mathrm{d}}$ Nitrogen permeability $\left(P \times 10^{11}\left[\mathrm{~mL}(\mathrm{STP}) \mathrm{cm} \cdot \mathrm{cm}^{-2} \cdot \mathrm{s}^{-1} \cdot(\mathrm{cm} \mathrm{Hg})^{-1}\right]\right.$ at $\left.25^{\circ} \mathrm{C}\right)$

${ }^{\mathrm{e}}$ Light transmission (\%) 
Table 3 Evolution of $\mathrm{N}_{2}, \mathrm{O}_{2}$, and $\mathrm{CO}_{2}$ over the storage period

\begin{tabular}{|c|c|c|c|c|c|}
\hline \multirow[t]{2}{*}{ Reference } & \multirow[t]{2}{*}{ Cheese type } & \multirow[t]{2}{*}{ MAP conditions $(\%)$} & \multicolumn{3}{|c|}{ Change observed } \\
\hline & & & $\mathrm{N}_{2}$ & $\mathrm{O}_{2}$ & $\mathrm{CO}_{2}$ \\
\hline $\begin{array}{l}\text { Garabal et } \\
\text { al. (2010) }\end{array}$ & $\begin{array}{l}\text { San Simon da } \\
\text { Costa (smoked } \\
\text { semi-hard cow's } \\
\text { milk cheeses) }\end{array}$ & $\begin{array}{r}\mathrm{VP}, 100 \mathrm{~N}_{2}, 20 \mathrm{CO}_{2} / 80 \\
\mathrm{~N}_{2} \text { and } 50 \mathrm{CO}_{2} / 50 \mathrm{~N}_{2}\end{array}$ & NA & Constant & $\begin{array}{l}\text { Increase (in } 100 \mathrm{~N}_{2} \text {, } \\
20 \mathrm{CO}_{2} / 80 \mathrm{~N}_{2} \text { ) and } \\
\text { decrease (in } 50 \\
\mathrm{CO}_{2} / 50 \mathrm{~N}_{2} \text { ) }\end{array}$ \\
\hline \multirow[t]{3}{*}{$\begin{array}{l}\text { Eliot et al. } \\
\quad(1998)\end{array}$} & \multirow[t]{3}{*}{ Mozzarella } & $\begin{array}{l}100 \mathrm{~N}_{2}, 10 \mathrm{CO}_{2} / 90 \mathrm{~N}_{2} \\
25 \mathrm{CO}_{2} / 75 \mathrm{~N}_{2} \text { and } 50 \\
\mathrm{CO}_{2} / 50 \mathrm{~N}_{2}\end{array}$ & Decrease & $\begin{array}{l}\text { Decrease, } \\
\text { except for } \\
\text { air which } \\
\text { had } \\
\text { increase }\end{array}$ & Increase \\
\hline & & $75 \mathrm{CO}_{2} / 25 \mathrm{~N}_{2}$ & Constant & Decrease & Constant \\
\hline & & $100 \mathrm{CO}_{2}$ & Increase & Decrease & Decrease \\
\hline \multirow{3}{*}{$\begin{array}{l}\text { Alves et al. } \\
\text { (1996) }\end{array}$} & \multirow[t]{3}{*}{ Mozzarella } & $100 \mathrm{~N}_{2}$ & Decrease & Decrease & Increase \\
\hline & & $100 \mathrm{CO}_{2}$ & Increase & Increase & Decrease \\
\hline & & $50 \mathrm{CO}_{2} / 50 \mathrm{~N}_{2}$ & Constant & Decrease & Decrease \\
\hline $\begin{array}{l}\text { Juric et al. } \\
\text { (2003) }\end{array}$ & $\begin{array}{l}\text { Rindless semi-hard } \\
\text { Samso }\end{array}$ & $\begin{array}{l}100 \mathrm{~N}_{2}, 20 \mathrm{CO}_{2} / 80 \mathrm{~N}_{2} \\
\quad \text { and } 100 \mathrm{CO}_{2}\end{array}$ & NA & Decrease & Increase \\
\hline $\begin{array}{l}\text { Maniar et al. } \\
\text { (1994) }\end{array}$ & Cottage & $\begin{array}{l}\text { Air, } 100 \mathrm{CO}_{2}, 75 \mathrm{CO}_{2} / \\
25 \mathrm{~N}_{2} \text {, and } 100 \mathrm{~N}_{2}\end{array}$ & Constant & NA & Constant \\
\hline \multirow[t]{2}{*}{$\begin{array}{l}\text { Trobetas et } \\
\text { al. }(2008)\end{array}$} & \multirow[t]{2}{*}{$\begin{array}{l}\text { Graviera } \\
\quad \text { (hard cheese) }\end{array}$} & $\begin{array}{c}100 \mathrm{CO}_{2}, 50 \mathrm{CO}_{2} / 50 \\
\mathrm{~N}_{2} \text {, and } 100 \mathrm{~N}_{2}\end{array}$ & NA & Constant & Constant \\
\hline & & Air & NA & Decrease & Increase \\
\hline $\begin{array}{l}\text { Kristensen et } \\
\text { al. (2000) }\end{array}$ & Havarti & $25 \mathrm{CO}_{2} / 75 \mathrm{~N}_{2}$ & NA & Constant & Constant \\
\hline $\begin{array}{l}\text { Pintado and } \\
\text { Malcata } \\
(2000)\end{array}$ & Requeijão & $\begin{array}{l}100 \mathrm{CO}_{2} \text { and } 50 \mathrm{CO}_{2} / \\
50 \mathrm{~N}_{2}\end{array}$ & NA & Constant & Constant \\
\hline $\begin{array}{l}\text { Olarte et al. } \\
\text { (2002) }\end{array}$ & $\begin{array}{l}\text { Cameros (fresh } \\
\text { goat cheese) }\end{array}$ & $\begin{array}{c}20 \mathrm{CO}_{2} / 80 \mathrm{~N}_{2}, 40 \mathrm{CO}_{2} / \\
60 \mathrm{~N}_{2} \text {, and } 100 \mathrm{CO}_{2}\end{array}$ & NA & Below 2\% & Decrease \\
\hline $\begin{array}{l}\text { Papaioannou } \\
\text { et al. } \\
(2007)\end{array}$ & Greek whey cheese & $\begin{array}{l}\text { VP, } 30 \mathrm{CO}_{2} / 70 \mathrm{~N}_{2} \text {, and } \\
\quad 70 \mathrm{CO}_{2} / 30 \mathrm{~N}_{2}\end{array}$ & Constant & Constant & Constant \\
\hline $\begin{array}{l}\text { Dermiki et } \\
\text { al. (2008) }\end{array}$ & $\begin{array}{l}\text { Myzithra Kalathaki } \\
\text { (whey cheese) }\end{array}$ & $\begin{array}{l}20 \mathrm{CO}_{2} / 80 \mathrm{~N}_{2}, 40 \mathrm{CO}_{2} / \\
60 \mathrm{~N}_{2} \text {, and } 60 \mathrm{CO}_{2} / 40 \\
\mathrm{~N}_{2}\end{array}$ & Increase & Constant & Decrease \\
\hline $\begin{array}{l}\text { Gammariello } \\
\text { et al. } \\
(2009 b)\end{array}$ & Stracciatella & $\begin{array}{l}\mathrm{VP}, 50 \mathrm{CO}_{2} / 50 \mathrm{~N}_{2}, 95 \\
\mathrm{CO}_{2} / 5 \mathrm{~N}_{2}, 75 \mathrm{CO}_{2} / 25 \\
\mathrm{~N}_{2} \text {, and } 30 \mathrm{CO}_{2} / 65 \\
\mathrm{~N}_{2} / 5 \mathrm{O}_{2}\end{array}$ & Constant & Constant & Constant \\
\hline $\begin{array}{l}\text { Esmer et al. } \\
\text { (2009) }\end{array}$ & $\begin{array}{l}\text { Crottin de } \\
\text { Chavignol }\end{array}$ & $\begin{array}{l}\text { Air, VP and } 50 \mathrm{CO}_{2} / 50 \\
\mathrm{~N}_{2}\end{array}$ & NA & Increase & Decrease \\
\hline $\begin{array}{l}\text { Rodriguez- } \\
\text { Aguilera } \\
\text { et al. } \\
\text { (2011b) }\end{array}$ & $\begin{array}{l}\text { Surface mold- } \\
\text { ripened }\end{array}$ & $\begin{array}{c}0 \mathrm{O}_{2} / 27 \pm 6 \mathrm{CO}_{2} \text { and } 2 \pm \\
1 \mathrm{O}_{2} / 19 \pm 2 \mathrm{CO}_{2}\end{array}$ & NA & Decrease & Increase \\
\hline
\end{tabular}

$N A$ not analyzed

$V P$ vacuum packaging 
- Increasing: $\mathrm{CO}_{2}$ production by the growth of aerobic and anaerobic microorganisms (Alves et al. 1996), hetero-fermentative Lactobacilli (Lee et al. 1990; Bellengier et al. 1993), yeasts activities (Belin 1990), and cheese respiration (Juric et al. 2003)

- Decreasing: $\mathrm{CO}_{2}$ dissolution into the cheese matrix, $\mathrm{CO}_{2}$ consumption by anaerobic microorganisms, and $\mathrm{CO}_{2}$ spreading out of the package (Moir et al. 1993; Ucuncu 2007)

$\mathrm{O}_{2}$ changes

- Remaining constant: Steady-state conditions between microbial respiration rate and $\mathrm{O}_{2}$ permeation through packaging materials (Maniar et al. 1994)

- Increasing: Coming from the trapped air between the slices (in sliced cheeses) and absorption to the EPS tray (Alves et al. 1996) and permeability of packaging film to $\mathrm{O}_{2}$ (Maniar et al. 1994)

- Decreasing: (1) Aerobic consumption by microorganisms, oxidative and enzymatic reactions involving oxygen (Fedio et al. 1994; Eliot et al. 1998) and (2) cheese respiration (Juric et al. 2003)

As far as $\mathrm{N}_{2}$ is concerned, its concentration inside the package is affected by $\mathrm{N}_{2}$ penetration into the package when its level becomes $<78 \%$ and a balanced relationship between $\mathrm{N}_{2}$ and $\mathrm{CO}_{2}$ levels [as $\mathrm{N}_{2}=100 \%$ - $\left(\% \mathrm{CO}_{2}+\% \mathrm{O}_{2}\right)$ ] (Alves et al. 1996; Eliot et al. 1998).

In addition to the used gas mixtures, there are some other factors affecting the inpack gas composition, including (1) permeability of package materials - retaining appropriate $\mathrm{CO}_{2}$ concentrations in headspace requires the use of high-barrier packaging materials (Mannheim and Soffer 1996); (2) light exposure-there are significant differences in $\mathrm{O}_{2}$ between cheese kept in the dark and cheese exposed to the light, which could be explained by oxidative reactions induced in the samples under the light leading to the increased $\mathrm{O}_{2}$ consumption (Juric et al. 2003; Trobetas et al. 2008); and (3) storage temperature - an increase in storage temperature is followed by the rise in $\mathrm{CO}_{2}$ and fall in $\mathrm{O}_{2}$ levels inside the package which, consequently, is evidence for the great impact of temperature on the gas exchange rate (Rodriguez-Aguilera et al. 2011a).

\subsection{Physicochemical properties}

Studies have introduced different gas mixtures for retarding the physicochemical deterioration such as oxidation, lipolysis, and proteolysis, which are summarized in Table 4.

\subsection{1 pH changes}

The presence of $\mathrm{CO}_{2}$ is expected to result in a $\mathrm{pH}$ drop, which is thought to be associated with the formation of carbonic acid, acidic amino acids, and free fatty acid production during proteolysis and lipolysis, respectively (Dermiki et al. 2008). $\mathrm{pH}$ reduction, caused by $\mathrm{CO}_{2}$ atmosphere, was reported in the literature (Farber 1991; Mannheim and Soffer 1996; Koskeli 1998) and was presumed as one of the 
Table 4 Changes in physicochemical properties, including $\mathrm{pH}$, oxidation, lipolysis, and proteolysis

\begin{tabular}{|c|c|c|c|c|c|}
\hline \multirow[t]{2}{*}{ Reference } & \multirow[t]{2}{*}{ Cheese type } & \multicolumn{4}{|l|}{ Gas mixture $(\%)$} \\
\hline & & $\mathrm{pH}^{\mathrm{a}}$ & Oxidation $^{\mathrm{b}}$ & Lipolysis $^{\mathrm{b}}$ & Proteolysis $^{\mathrm{b}}$ \\
\hline Maniar et al. (1994) & Cottage & $100 \mathrm{CO}_{2}$ & NA & NA & NA \\
\hline $\begin{array}{l}\text { Pintado and Malcata } \\
\text { (2000) }\end{array}$ & Requeijão & NA & NA & $\begin{array}{l}100 \mathrm{CO}_{2} \\
\text { for all } \\
\text { temperature } \\
\text { treatments; } \\
50 \mathrm{CO}_{2} / 50 \mathrm{~N}_{2} \\
\text { and } 100 \mathrm{~N}_{2} \\
\text { at } 4{ }^{\circ} \mathrm{C}\end{array}$ & NA \\
\hline Olarte et al. (2002) & $\begin{array}{c}\text { Cameros (fresh } \\
\text { goat cheese) }\end{array}$ & $100 \mathrm{CO}_{2}$ & NA & NA & NA \\
\hline Dermiki et al. (2008) & $\begin{array}{l}\text { Myzithra Kalathaki } \\
\text { (whey cheese) }\end{array}$ & $60 \mathrm{CO}_{2} / 40 \mathrm{~N}_{2}$ & $40 \mathrm{CO}_{2} / 60 \mathrm{~N}_{2}$ & $40 \mathrm{CO}_{2} / 60 \mathrm{~N}_{2}$ & $40 \mathrm{CO}_{2} / 60 \mathrm{~N}_{2}$ \\
\hline $\begin{array}{l}\text { Gammariello et al. } \\
\text { (2009b) }\end{array}$ & Stracciatella & $30 \mathrm{CO}_{2} / 65 \mathrm{~N}_{2} / 5 \mathrm{O}_{2}$ & NA & NA & NA \\
\hline Esmer et al. (2009) & Crottin de Chavignol & $20 \mathrm{CO}_{2} / 80 \mathrm{~N}_{2}$ & NA & NA & NA \\
\hline $\begin{array}{l}\text { Rodriguez-Aguilera } \\
\text { et al. }(2011 \mathrm{~b})\end{array}$ & $\begin{array}{l}\text { Surface mold- } \\
\text { ripened }\end{array}$ & $0 \mathrm{O}_{2} / 27 \pm 6 \mathrm{CO}_{2}$ & NA & NA & NA \\
\hline Favati et al. (2007) & Provolone & $\begin{array}{l}100 \mathrm{CO}_{2} \text { and } \\
20 \mathrm{CO}_{2} / 80 \mathrm{~N}_{2}\end{array}$ & NA & $30 \mathrm{CO}_{2} / 70 \mathrm{~N}_{2}$ & VP \\
\hline \multirow[t]{2}{*}{$\begin{array}{l}\text { Gammariello et al. } \\
\text { (2009a) }\end{array}$} & $\begin{array}{l}\text { Giuncata (Apulian } \\
\text { fresh cheeses) }\end{array}$ & VP & NA & NA & NA \\
\hline & $\begin{array}{l}\text { Primosale (Apulian } \\
\text { fresh cheeses) }\end{array}$ & $90 \mathrm{CO}_{2} / 10 \mathrm{~N}_{2}$ & NA & NA & NA \\
\hline Temiz et al. (2009) & $\begin{array}{l}\text { Lor (Turkish } \\
\text { whey cheese) }\end{array}$ & $70 \mathrm{CO}_{2} / 30 \mathrm{~N}_{2}$ & $70 \mathrm{CO}_{2} / 30 \mathrm{~N}_{2}$ & $40 \mathrm{CO}_{2} / 60 \mathrm{~N}_{2}$ & NA \\
\hline Temiz (2010) & Kashar & $100 \mathrm{CO}_{2}$ & NA & NA & NA \\
\hline
\end{tabular}

\footnotetext{
${ }^{\mathrm{a}}$ Final lowest $\mathrm{pH}$ value obtained

${ }^{\mathrm{b}}$ Optimal gas mixture in retarding the given physicochemical property

$N A$ not analyzed, $V P$ vacuum packaging
}

mechanisms for microbial growth inhibition by $\mathrm{CO}_{2}$ (King and Nagel 1967; Daniels et al. 1985). Mannheim and Soffer (1996), in their study evaluating the shelf life extension of Cottage cheese by MAP (pure $\mathrm{CO}_{2}$ at $8{ }^{\circ} \mathrm{C}$ storage), observed a drop in the value. Despite the expected depression in $\mathrm{pH}$ values, there are various reports in the literature.

The comparison between samples under vacuum, air, and MAP atmosphere at $4{ }^{\circ} \mathrm{C}$ showed higher $\mathrm{pH}$ values in MAP-packaged whey cheeses (Myzithra Kalathaki), which lowered as a portion of the $\mathrm{CO}_{2}$ increase in the $\mathrm{CO}_{2} / \mathrm{N}_{2}$ ratio ( $\mathrm{pH}$ values order for $\mathrm{CO}_{2} / \mathrm{N}_{2}, 20 / 80>40 / 60>60 / 40$; Dermiki et al. 2008). This higher value was attributed to the higher lactic acid bacteria (LAB) counts of air and vacuum packaging treatments, which resulted in high lactic acid production with a consequent drop in $\mathrm{pH}$ value. However, Moir et al. (1993) found that the presence of $\mathrm{CO}_{2}$ had no effect on the $\mathrm{pH}$ values of Cottage cheese. Possibly, $\mathrm{CO}_{2}$ absorption occurred mainly on the surface of the samples rather 
than into the total matrix, the result of which was the acidification of just some spots. Increase in $\mathrm{pH}$ values was also reported in a study conducted by Maniar et al. (1994) on direct-set Cottage cheese stored at $4{ }^{\circ} \mathrm{C}$ and was justified as the absorption of the produced acid by the curd from the cream. Garabal et al. (2010) associated their observation, about the $\mathrm{pH}$ increase, in industrially made smoked semi-hard cheese (San Simón da Costa, from cow's milk), which increased from 5.25 in ripened cheese to 5.45, 5.46, and 5.40 for gas mixtures of $100 \% \mathrm{~N}_{2}, 20 \% \mathrm{CO}_{2} / 80 \% \mathrm{~N}_{2}$, and $50 \% \mathrm{CO}_{2} / 50 \% \mathrm{~N}_{2}$, respectively, after 45 days of storage, to proteolysis and associated formation of amines and ammonium. Temiz (2010) observed an increase in the $\mathrm{pH}$ values of sliced Kashar cheese, which was followed by a subsequent depression as the lowest final $\mathrm{pH}$ value (5.70) was determined in cheese under $100 \% \mathrm{CO}_{2}$. The $\mathrm{pH}$ increase was thought to be associated with the consumption of lactic acid by molds and yeast, proteolytic events, which would release large amounts of alkaline components (Prieto et al. 2000; Awad 2006), and the next reduction related to $\mathrm{CO}_{2}$ presence, which was expected to cause a decrease in $\mathrm{pH}$ because of the formation of carbonic acid (Dermiki et al. 2008).

Additionally, cheese type and storage temperature are the parameters which should be considered significant in $\mathrm{pH}$ changes. For instance, the increase in the $\mathrm{pH}$ level of MAP-packaged surface mold-ripened soft cheeses (Rodriguez-Aguilera et al. 2011b), well known for this kind of cheese, was considered to be related to the metabolism of lactic acid, deamination of amino acids, and the release of $\mathrm{NH}_{3}$ caused by activity of the mold on the surface of the cheese (Sousa and McSweeney 2001). Monitoring the storage temperature, especially at the last stages of storage, is another critical parameter since Pintado and Malcata (2000), in their study on the optimization of MAP $\left(100 \% \mathrm{CO}_{2}\right.$ and $\left.50 \% \mathrm{CO}_{2} / 50 \% \mathrm{~N}_{2}\right)$ for Requeijao cheese, reported that storing cheese above refrigeration temperatures (i.e., 12 or $18{ }^{\circ} \mathrm{C}$ ) results in great $\mathrm{pH}$ drop.

\subsubsection{Oxidation}

Oxidative damage, for all various kinds of cheese, is a well-known destructive event which emerges as undesirable modifications in flavor, odor, and appearance. To restrict the damage caused by oxidation, the contributors such as oxygen availability and light exposure should be eliminated or reduced.

With respect to retard oxidation, vacuum packaging is one of the most recommended techniques, whereas in the aspect of cheese as a target, to shield it against oxygen-related deterioration is not most appropriate considering possible undesirable changes in the structure and appearance characteristics of some kinds of cheese encountered. Instead, MAP has been suggested as a reliable technique to minimize any undesirable changes in sensory characteristics, along with extending the product shelf life (Romani et al. 2002).

Researchers have reported contradictory results on the influence of light exposure to the oxidation of cheese samples packaged with MAP. Trobetas et al. (2008) studied light-induced changes in grated Graviera hard cheese packaged under modified atmospheres $\left(100 \% \mathrm{CO}_{2}, 100 \% \mathrm{~N}_{2}\right.$, and $\left.50 \% \mathrm{CO}_{2} / 50 \% \mathrm{~N}_{2}\right)$ and showed that the degree of oxidation for samples kept away from light compared 
with light-exposed samples was significantly lower. Absorbance values for the former were $>0.04 \%$ while for the latter between $0.06 \%$ and $1.0 \%$.

However, Kristensen et al. (2000), in their study on light-induced oxidation in sliced Havarti cheese under modified atmosphere $\left(25 \% \mathrm{CO}_{2} / 75 \% \mathrm{~N}_{2}\right.$ with initial $\left.0.4 \% \mathrm{O}_{2}\right)$ exposed to light $(1,000 \mathrm{~lx})$ and stored at $5{ }^{\circ} \mathrm{C}$, found no significant difference between all treatments, either under light or in the dark.

Temiz et al. (2009) observed a peak point in the lipid oxidation figure of Turkish whey cheeses (Lor) stored at $4{ }^{\circ} \mathrm{C}$, in all treatments on day 31 of storage, so that gaseous atmosphere of $60 \%$ and $70 \% \mathrm{CO}_{2}$ exhibited lower oxidation. Thiobarbituric acid values, after approaching the maximum value on the 31 st day of storage, declined with prolonged storage time, which could be explained by the interaction between malonaldehyde and the decomposition products of proteins in order to produce tertiary degradation products (Nawar 1996). At the end of storage (45 days), samples in package containing $70 \% \mathrm{CO}_{2}$ presented the lowest oxidation value.

\subsubsection{Lipolysis}

The degree of lipolysis is expressed as milliliters of $0.01 \mathrm{~N} \mathrm{KOH}$ based on the procedure described by the International Dairy Federation (IDF 1989). Lipolysis is also a significant biochemical event in creating the final flavor of cheese (Georgala et al. 2005; Guler 2005). Lipolytic enzymes originated in milk, microorganisms, and probably the rennet (Poveda et al. 2000). Temiz et al. (2009) observed an increase in the acidity index (AI) of Turkish whey cheese for all the samples which was followed by a decrease after reaching the peak value on day 31 of storage. At the end of storage, air- and vacuum-packaged samples, when compared with the MAP ones (under $40 \%, 60 \%$, and $70 \% \mathrm{CO}_{2}$ ), had a higher AI value, and out of the three modified atmospheres, the highest amounts of AI were determined in the $40 \% \mathrm{CO}_{2} / 60 \% \mathrm{~N}_{2}$ gas mixture. The authors related this to the decomposition of free fatty acids, principally via the oxidation of methyl ketones (Prieto et al. 2000). However, Gonzalez-Fandos et al. (2000) found no significant differences among the combinations of $\mathrm{CO}_{2} / \mathrm{N}_{2}\left(20 \% \mathrm{CO}_{2} /\right.$ $80 \% \mathrm{~N}_{2}, 40 \% \mathrm{CO}_{2} / 60 \% \mathrm{~N}_{2}, 50 \% \mathrm{CO}_{2} / 50 \% \mathrm{~N}_{2}$, and $100 \% \mathrm{CO}_{2}$ ) stored at $3-4{ }^{\circ} \mathrm{C}$ studied in retarding the lipolysis of Cameros cheese.

\subsubsection{Proteolysis}

The degree of proteolysis is expressed in terms of the free amino acids present in the sample. Gonzalez-Fandos et al. (2000) found that the highest degree of proteolysis was detected in the control and vacuum-packaged Cameros cheese. They explained it with the observed higher counts of microorganisms in them in comparison with MA-packed samples. Although no significant difference was reported between applied modified atmospheres $\left(20 \%, 40 \%, 50 \%\right.$, and $\left.100 \% \mathrm{CO}_{2}\right)$. Dermiki et al. (2008), as well, reported that proteolysis of packaged Myzithra Kalathaki cheeses under MAP was significantly lower than the rest of the samples. However, they demonstrated that the applied gaseous combinations $\left(20 \%, 40 \%\right.$, and $\left.60 \% \mathrm{CO}_{2}\right)$ 
were not effective in preventing the proteolysis; the observed reduction was considered to be related to the resistance of albumin and whey proteins $(\alpha-$ lactalbumin and $\beta$-lactoglobulin) present in the cheese against the action of psychrotrophic proteases rather than the effect of $\mathrm{CO}_{2}$ concentration. Moreover, fluctuation was observed in the degree of proteolysis, which might be attributed to the consumption of proteolysis products as nutrients by increasing the microbial population (Lioliou et al. 2001).

However, in the study conducted on whey cheese (Manouri) by Dermiki et al. (2008), there was no significant increase in the degree of proteolysis in the cheese samples despite the presence of proteolytic as the main spoilage bacteria (Enterobacteriaceae and Staphylococci). This was attributed to the failure of caseinolytic bacteria present in Manouri cheese, degrading whey proteins (Lioliou et al. 2001).

\subsubsection{Moisture content and weight loss}

Moisture content is an important factor in cheese packaging from the economic point of view and for keeping the cheese fresh. Rodriguez-Aguilera et al. (2011b) demonstrated that surface mold-ripened cheese packed under MAP condition of $0 \%$ $\mathrm{O}_{2} / 27 \pm 6 \% \mathrm{CO}_{2}$ exhibited the lowest values of moisture content. There was no significant difference between the control and the gas mixture of $2 \pm 1 \% \mathrm{O}_{2} / 19 \pm 2 \%$ $\mathrm{CO}_{2}$. However, the latter resulted in almost no weight loss. Others have indicated that different gas mixtures did not significantly influence the moisture content or weight loss in the cheese when packaged under modified atmospheres. However, MAP conditions were reported as slightly efficient in keeping the moisture content of cheese stable (San Simón da Costa smoked semi-hard: Garabal et al. 2010; Greek whey: Papaioannou et al. 2007; Provolone: Favati et al. 2007; Primosale and Giuncata: Gammariello et al. 2009a; Lor Turkish whey cheese: Temiz et al. 2009; Parmigiano-Reggiano cheese: Romani et al. 2002).

There are, though, observations reporting a decrease in moisture content during storage for all cheese samples, and the statistically significant differences were found between the Cameros cheese packaged in MAP and the rest of package treatments in which MAP was preferable. However, these studies, as well as Sendra et al. (1994), in a study on goat fresh cheese, reported that the highest weight losses were found in samples packaged under $100 \% \mathrm{CO}_{2}$.

\subsubsection{Dry matter, protein, fat, and salt (\%)}

Papaioannou et al. (2007) (Greek whey cheese) and Favati et al. (2007) (Provolone cheese) obtained no significant difference between MAP and control samples from dry matter, protein, fat, and salt percentage aspects. However, other authors reported an increase in the mentioned properties (Kristensen et al. 2000 for Havarti cheese: dry matter-from $61.7 \pm 0.6$ to $65.6 \pm 0.8$ in light and $64.3 \pm 1.3$ in dark; Temiz et al. 2009 for Turkish whey cheese: dry matter-from 34.56 to 35.587 , protein-from 10.51 to 10.69 , fat-from 15.5 to 16 , and salt-from 3.65 to 3.79 ; Trobetas et al. 2008 for Gravira hard cheese: fat—from 30.2 to 31.8 ). 


\subsection{Microbiological analyses}

Variables such as milk quality, survival of heat-sensitive microorganisms during cheese making, and post-processing microbial contamination all influence the microbiology of the cheese (Del Nobile et al. 2009). Table 5 presents the studied microorganisms and optimal gas mixtures for each given microorganism in inhibiting the microbial growth for the cheese packed under a modified atmosphere. Other studies have pointed out the significant effect of MAP containing $\mathrm{CO}_{2}$ in preventing the cheese from microbial spoilage and prolonging their shelf life, which shows the destructive impact of $\mathrm{CO}_{2}$ on the spoilage microbes. The inhibitory effect of $\mathrm{CO}_{2}$ on microbial spoilage could be explained by the increase in the lag phase and the decrease in the growth rate over a logarithmic phase (Farber 1991) because microorganisms have to adapt to the new atmospheric conditions (Olarte et al. 2002). There are some theories regarding the antimicrobial properties of carbon dioxide (Farber 1991; Pintado and Malcata 2000), which include:

- Malfunctions in cell membrane, such as glucose and free amino acid uptake/ absorption

- Direct physicochemical changes of membrane-located proteins and lipids;

- Inhibition of enzyme systems directly or depression in the rate of enzymatic reactions

- Intracellular $\mathrm{pH}$ change

- Inhibiting cell division and altering cell morphology

\subsubsection{Lactic acid bacteria}

Articles show that LAB were slightly affected under the modified atmospheres and were able to grow well (Mozzarella cheese: Eliot et al. 1998; Cottage cheese: Maniar et al. 1994; Greek whey cheese: Papaioannou et al. 2007; whey cheese: Dermiki et al. 2008; Apulian fresh cheese: Gammariello et al. 2009a; Turkish whey cheese: Temiz et al. 2009) since LAB are facultative anaerobic Gram-positive in nature. The inefficiency of the MAP packaging on these useful dairy bacteria has become a suitable advertising tool to increasingly market dairy products with MAP as being "preservative-free and rich in viable lactic acid bacteria" (Coppola et al. 1995). However, Maniar et al. (1994) showed that LAB counts of Cottage cheese (with gas mixture of $100 \% \mathrm{CO}_{2}, 75 \%$ $\mathrm{CO}_{2} / 25 \% \mathrm{~N}_{2}$, and $100 \% \mathrm{~N}_{2}$ ) remained constant and independent from MAP effect, which was possibly due to the low storage temperature $\left(4^{\circ} \mathrm{C}\right)$ applied in their study. These findings agree with the results in a study conducted by Papaioannou et al. (2007) on Greek whey cheese in which the higher LAB counts were measured at $12^{\circ}$ $\mathrm{C}$ rather than $4{ }^{\circ} \mathrm{C}$, for all the cheese samples.

\subsubsection{Psychrotrophic bacteria}

Maniar et al. (1994) reported that psychrotrophic bacteria counts remained unchanged for Cottage cheese with modified atmospheres $\left(100 \% \mathrm{CO}_{2}, 75 \% \mathrm{CO}_{2} /\right.$ $25 \% \mathrm{~N}_{2}$, and $100 \% \mathrm{~N}_{2}$ ). The absence of $\mathrm{O}_{2}$ from the package headspace, because psychrotrophic bacteria are aerobes, and the bacteriostatic properties of $\mathrm{CO}_{2}$ may 
Table 5 Studied microorganisms and optimal gas mixture in inhibiting microbial growth

\begin{tabular}{|c|c|c|c|c|c|c|c|c|}
\hline \multirow[t]{2}{*}{ Reference } & \multirow[t]{2}{*}{ Cheese type } & \multicolumn{7}{|c|}{ Optimal gas mixture $(\%)^{\mathrm{a}}$} \\
\hline & & $\begin{array}{l}\text { Lactic acid } \\
\text { bacteria } \\
(\mathrm{LAB})\end{array}$ & $\begin{array}{l}\text { Psychrotrophic } \\
\text { bacteria }\end{array}$ & Mesophilic bacteria & $\begin{array}{l}\text { Pseudomonas } \\
\text { spp. }\end{array}$ & Yeasts & Molds & Enterobacteriaceace \\
\hline $\begin{array}{l}\text { Garabal et al. } \\
(2010)\end{array}$ & $\begin{array}{l}\text { San Simon da } \\
\text { Costa }\end{array}$ & NA & NA & $50 \mathrm{CO}_{2} / 50 \mathrm{~N}_{2}$ & NA & $\geq 50 \mathrm{CO}_{2}$ & $\geq 50 \mathrm{CO}_{2}$ & NA \\
\hline $\begin{array}{l}\text { Eliot et al. } \\
\text { (1998) }\end{array}$ & Mozzarella & $75 \mathrm{CO}_{2} / 25 \mathrm{~N}_{2}$ & $75 \mathrm{CO}_{2} / 25 \mathrm{~N}_{2}$ & $75 \mathrm{CO}_{2} / 25 \mathrm{~N}_{2}$ & NA & $\begin{array}{c}50 \mathrm{CO}_{2} / 50 \mathrm{~N}_{2} \\
100 \mathrm{~N}_{2}, 100 \\
\mathrm{CO}_{2}\end{array}$ & $10-100 \% \mathrm{CO}_{2}$ & NA \\
\hline $\begin{array}{l}\text { Alves et al. } \\
\text { (1996) }\end{array}$ & Mozzarella & NA & $100 \mathrm{CO}_{2}$ & NA & NA & $100 \mathrm{CO}_{2}$ & $100 \mathrm{CO}_{2}$ & NA \\
\hline $\begin{array}{l}\text { Maniar et al. } \\
\text { (1994) }\end{array}$ & Cottage & $75 \mathrm{CO}_{2} / 25 \mathrm{~N}_{2}$ & $75 \mathrm{CO}_{2} / 25 \mathrm{~N}_{2}$ & NA & NA & NA & NA & NA \\
\hline $\begin{array}{l}\text { Mannheim and } \\
\text { Soffer (1996) }\end{array}$ & Cottage & NA & NA & NA & NA & $100 \mathrm{CO}_{2}$ & $100 \mathrm{CO}_{2}$ & NA \\
\hline $\begin{array}{l}\text { Olarte et al. } \\
(2002)\end{array}$ & $\begin{array}{c}\text { Cameros (fresh } \\
\text { goat cheese) }\end{array}$ & NA & $100 \mathrm{CO}_{2}$ & $100 \mathrm{CO}_{2}$ & NA & NA & NA & NA \\
\hline $\begin{array}{l}\text { Papaioannou et } \\
\text { al. (2007) }\end{array}$ & $\begin{array}{l}\text { Greek whey } \\
\text { cheese }\end{array}$ & $70 \mathrm{CO}_{2} / 30 \mathrm{~N}_{2}$ & NA & $70 \mathrm{CO}_{2} / 30 \mathrm{~N}_{2}$ & $70 \mathrm{CO}_{2} / 30 \mathrm{~N}_{2}$ & $70 \mathrm{CO}_{2} / 30 \mathrm{~N}_{2}$ & $70 \mathrm{CO}_{2} / 30 \mathrm{~N}_{2}$ & $70 \mathrm{CO}_{2} / 30 \mathrm{~N}_{2}$ \\
\hline $\begin{array}{l}\text { Dermiki et al. } \\
(2008)\end{array}$ & $\begin{array}{l}\text { Myzithra } \\
\text { Kalathaki (whey } \\
\text { cheese) }\end{array}$ & $40 \mathrm{CO}_{2} / 60 \mathrm{~N}_{2}$ & $40 \mathrm{CO}_{2} / 60 \mathrm{~N}_{2}$ & $40 \mathrm{CO}_{2} / 60 \mathrm{~N}_{2}$ & NA & $\begin{array}{c}40 \mathrm{CO}_{2} / 60 \mathrm{~N}_{2}, 60 \\
\mathrm{CO}_{2} / 40 \mathrm{~N}_{2}\end{array}$ & $\begin{array}{l}40 \mathrm{CO}_{2} / 60 \mathrm{~N}_{2} \\
\quad 60 \mathrm{CO}_{2} / 40 \mathrm{~N}_{2}\end{array}$ & $\begin{array}{c}40 \mathrm{CO}_{2} / 60 \mathrm{~N}_{2}, 60 \\
\mathrm{CO}_{2} / 40 \mathrm{~N}_{2}\end{array}$ \\
\hline $\begin{array}{l}\text { Gammariello et } \\
\text { al. }(2009 b)\end{array}$ & Stracciatella & $\mathrm{DN}$ & $\mathrm{DN}$ & $95 \mathrm{CO}_{2} / 5 \mathrm{~N}_{2}$ & $75 \mathrm{CO}_{2} / 25 \mathrm{~N}_{2}$ & $\mathrm{DN}$ & $\mathrm{DN}$ & $95 \mathrm{CO}_{2} / 5 \mathrm{~N}_{2}$ \\
\hline $\begin{array}{l}\text { Esmer et al. } \\
(2009)\end{array}$ & $\begin{array}{l}\text { Crottin de } \\
\text { Chavignol }\end{array}$ & NA & NA & $20 \mathrm{CO}_{2} / 80 \mathrm{~N}_{2}$ & NA & $20 \mathrm{CO}_{2} / 80 \mathrm{~N}_{2}$ & $20 \mathrm{CO}_{2} / 80 \mathrm{~N}_{2}$ & NA \\
\hline
\end{tabular}


Table 5 (continued)

\begin{tabular}{|c|c|c|c|c|c|c|c|c|}
\hline \multirow[t]{2}{*}{ Reference } & \multirow[t]{2}{*}{ Cheese type } & \multicolumn{7}{|c|}{ Optimal gas mixture $(\%)^{\mathrm{a}}$} \\
\hline & & $\begin{array}{l}\text { Lactic acid } \\
\text { bacteria } \\
(\mathrm{LAB})\end{array}$ & $\begin{array}{l}\text { Psychrotrophic } \\
\text { bacteria }\end{array}$ & Mesophilic bacteria & $\begin{array}{l}\text { Pseudomonas } \\
\text { spp. }\end{array}$ & Yeasts & Molds & Enterobacteriaceace \\
\hline $\begin{array}{l}\text { Favati et al. } \\
\qquad(2007)\end{array}$ & Provolone & $30 \mathrm{CO}_{2} / 70 \mathrm{~N}_{2}$ & $100 \mathrm{CO}_{2}$ & $\begin{array}{l}100 \mathrm{CO}_{2} \text { (for aerobic) } \\
\text { and VP (for anaerobic) }\end{array}$ & NA & $100 \mathrm{CO}_{2}$ & $20 \mathrm{CO}_{2} / 80 \mathrm{~N}_{2}$ & NA \\
\hline $\begin{array}{l}\text { Gammariello et } \\
\text { al. (2009a) }\end{array}$ & $\begin{array}{l}\text { Apulian fresh } \\
\text { cheeses }\end{array}$ & $50 \mathrm{CO}_{2} / 50 \mathrm{~N}_{2}$ & NA & $\mathrm{DN}$ & $\begin{array}{l}50 \mathrm{CO}_{2} / 50 \mathrm{~N}_{2} \\
\quad 90 \mathrm{CO}_{2} / 10 \mathrm{~N}_{2}\end{array}$ & $\mathrm{DN}$ & ND & NA \\
\hline $\begin{array}{l}\text { Temiz et al. } \\
\text { (2009) }\end{array}$ & $\begin{array}{l}\text { Lor (Turkish } \\
\text { whey cheese) }\end{array}$ & $60 \mathrm{CO}_{2} / 40 \mathrm{~N}_{2}$ & $40 \mathrm{CO}_{2} / 60 \mathrm{~N}_{2}$ & $\begin{array}{l}60 \mathrm{CO}_{2} / 40 \mathrm{~N}_{2} \\
\quad 70 \mathrm{CO}_{2} / 30 \mathrm{~N}_{2}\end{array}$ & NA & $\begin{array}{l}60 \mathrm{CO}_{2} / 40 \mathrm{~N}_{2} \\
\quad 70 \mathrm{CO}_{2} / 30 \mathrm{~N}_{2}\end{array}$ & $\begin{array}{l}60 \mathrm{CO}_{2} / 40 \mathrm{~N}_{2} \\
\quad 70 \mathrm{CO}_{2} / 30 \mathrm{~N}_{2}\end{array}$ & $70 \mathrm{CO}_{2} / 30 \mathrm{~N}_{2}$ \\
\hline Temiz (2010) & Kashar & NA & NA & $100 \mathrm{CO}_{2}$ & NA & $100 \mathrm{CO}_{2}$ & $100 \mathrm{CO}_{2}$ & NA \\
\hline $\begin{array}{l}\text { Gonzalez- } \\
\text { Fandos et al. } \\
(2000)\end{array}$ & Cameros & NA & $100 \mathrm{CO}_{2}$ & $100 \mathrm{CO}_{2}$ & NA & ND & ND & $100 \mathrm{CO}_{2}$ \\
\hline $\begin{array}{l}\text { Del Nobile et al. } \\
\text { (2009) }\end{array}$ & Ricotta & $95 \mathrm{CO}_{2} / 5 \mathrm{~N}_{2}$ & $95 \mathrm{CO}_{2} / 5 \mathrm{~N}_{2}$ & $95 \mathrm{CO}_{2} / 5 \mathrm{~N}_{2}$ & $95 \mathrm{CO}_{2} / 5 \mathrm{~N}_{2}$ & $\begin{array}{l}95 \mathrm{CO}_{2} / 5 \mathrm{~N}_{2} \\
\quad 70 \mathrm{CO}_{2} / 30 \mathrm{~N}_{2}\end{array}$ & ND & $70 \mathrm{CO}_{2} / 30 \mathrm{~N}_{2}$ \\
\hline
\end{tabular}

${ }^{\text {a }}$ Optimal gas mixture for best preservation against given microbial target.

$N A$ not analyzed, $N D$ not detected, $D N$ data not shown, $V P$ vacuum packaging 
explain this observation (Brody 1989). Alves et al. (1996) demonstrated that MAP $\left(100 \% \mathrm{CO}_{2}\right)$ was able to retard just the beginning of the psychrotrophic bacteria growth in Mozzarella cheese, which was confirmed by others (Pintado and Malcata 2000 on Requeijão cheese; Gammariello et al. 2009a on Apulian fresh cheeses). Also, Eliot et al. (1998) found that there was psychrotroph growth during the first weeks of storage for those with the modified atmospheres under study $(10 \%, 25 \%$, $50 \%, 75 \%, 100 \% \mathrm{~N}_{2}$ ) since psychrophiles are a complex population and species in Mozzarella cheeses are resistant to $\mathrm{CO}_{2}$ inhibitory effect.

In addition, different storage temperatures $\left(10^{\circ} \mathrm{C}\right.$ by Moir et al. 1993 on Cottage cheese; $7{ }^{\circ} \mathrm{C}$ by Alves et al. 1996 on Mozzarella cheese; $10^{\circ} \mathrm{C}$ by Eliot et al. 1998 on Cameros cheese; $4{ }^{\circ} \mathrm{C}$ by Gonzalez-Fandos et al. 2000 on Cameros cheese) were evaluated as a possible contributor means for MAP in controlling psychrotrophic bacteria growth, and applying low temperatures was found to be a fruitful hurdle in combination with MAP. Due to lower temperatures, the higher $\mathrm{CO}_{2}$ solubility leads to a higher inhibitory effect of $\mathrm{CO}_{2}$.

\subsubsection{Other studied microorganisms}

In addition to the investigated microorganisms, presented in Table 5, a number of articles have studied the effect of MAP on some other bacteria with healthrelated concerns and found it to be an efficient means to control or even inhibit their growth.

\subsubsection{Staphylococci}

Eliot et al. (1998) studied the growth of staphylococci under different MAP conditions $\left(10 \%, 25 \%, 50 \%, 100 \% \mathrm{CO}_{2}\right.$, and $100 \% \mathrm{~N}_{2}$ on Mozzarella cheese). Its growth was inhibited in all studied treatments; the counts of staphylococci were $1 \log$ CFU.g ${ }^{-1}$ after 8 weeks storage and did not meet the suggested microbial threshold of $10^{7}$ CFU.g ${ }^{-1}$ (ICMSF 1978).

\subsubsection{Coliforms}

Gammariello et al. (2009a, b) explained that the viable cell concentration of coliforms slightly declined up to day 8 of storage for all treatments. In particular, among the MAPs studied, the gas mixtures of $95 \% \mathrm{CO}_{2} / 5 \% \mathrm{~N}_{2}$ for Apulian fresh cheeses and $75 \% \mathrm{CO}_{2} /$ $25 \% \mathrm{~N}_{2}$ for Stracciatella, respectively, were the most effective for the inhibition of these spoilage microorganisms, supporting the results obtained in Gonzalez-Fandos et al. (2000) which showed that $\mathrm{CO}_{2}$ had an inhibitory effect on coliforms on Cameros cheese; later, they introduced plain $\mathrm{CO}_{2}$ as an optimum gas combination. Moreover, Mannheim and Soffer (1996) reported that coliform counts were about 1 log cycle higher in control Cottage cheese when compared with the samples flushed with pure $\mathrm{CO}_{2}$.

\subsubsection{Listeria monocytogenes}

Since the 1970s, Listeria monocytogenes has been introduced as a food-borne pathogen. Not only vegetables and meat but also certain kinds of cheeses were 
proven to be ideal media for Listeria growth (Genigeorgis et al. 1991; Mossel et al. 1995). The reported outbreaks of listeriosis associated with the consumption of Mexican-style cheese from California (James et al. 1985), Mexican soft cheeses (Linnan et al. 1988), and Vacherin Mont D'Or (Bille 1990) have caused great concern toward L. monocytogenes. Previously, Chen and Hotchkiss (1991) pointed out the inhibitory effect of $\mathrm{CO}_{2}$ on L. monocytogenes, especially in a hurdle manner with low-temperature storage $\left(4^{\circ} \mathrm{C}\right)$ and $\mathrm{pH}$ in Cottage cheese. For preventing Listeria growth, Whitley et al. (2000) found that an increase in the $\mathrm{CO}_{2}$ level to $20 \%$ $\left(20 \% \quad \mathrm{CO}_{2} / 80 \% \quad \mathrm{~N}_{2}\right)$ was more efficient than a simple reduction in the $\mathrm{O}_{2}$ concentration $\left(80 \% \mathrm{~N}_{2} / 10 \% \mathrm{CO}_{2} / 10 \% \mathrm{O}_{2}\right)$ of the package headspace surrounding ripened mold cheese (Stilton) at refrigeration temperatures $\left(2-8{ }^{\circ} \mathrm{C}\right)$. However, they concluded that MAP in either $10 \%$ or $20 \% \mathrm{CO}_{2}$ did not have the potential for controlling the growth of L. monocytogenes in a mold-ripened cheese. Olarte et al. (2002) incubated Cameros cheese inoculated with this pathogen and examined the effectiveness of MAP $\left(20 \%, 40 \%\right.$, and $\left.100 \% \mathrm{CO}_{2}\right)$ on its growth inhibition and found pure $\mathrm{CO}_{2}$ effective in declining the growth rate of L. monocytogenes, but not inhibition. They even showed that L. monocytogenes was able to grow in the cheese samples stored at low temperature $\left(4^{\circ} \mathrm{C}\right)$ during the storage period. The availability of suitable growth conditions in cheese composition (no starter culture, near-neutral $\mathrm{pH}$, low salt content, and high moisture content), wide range of growth temperature of this bacterium (from -1 to $45{ }^{\circ} \mathrm{C}$ ), and overlapping the $\mathrm{pH}$ levels (6-6.7) of Cameros cheeses with $\mathrm{pH}$ range for the growth of Listeria ( $\mathrm{pH}$ range of 4.1-9.6 with an optimum in the region of $\mathrm{pH} \mathrm{6)} \mathrm{might} \mathrm{cause} \mathrm{the} \mathrm{growth} \mathrm{of} \mathrm{the} \mathrm{microorganisms} \mathrm{in}$ this type of cheese (Whitley et al. 2000).

In contrast, Moir et al. (1993) did not observe growth of L. monocytogenes inoculated into Cottage cheese packaged in air or $40 \% \mathrm{CO}_{2} / 60 \% \mathrm{~N}_{2}$. The ability of $L$. monocytogenes to grow in Cottage cheese probably resulted from the low $\mathrm{pH}$ of this type of cheese (Bahk and Marth 1990). It is worth noting that since the organism is not generally known as thermoduric, most thermal processes such as pasteurization should be able to easily eliminate Listeria species from foods (Donnelly and Briggs 1986).

\subsubsection{Clostridium sporogenes}

To the best of our knowledge, Chen and Hotchkiss (1991) were the only investigators who monitored the growth of Clostridium sporogenes in inoculated Cottage cheese, applying dissolved carbon dioxide, in which they did not observe a significant effect of $\mathrm{CO}_{2}$ on $C$. sporogenes growth. No growth was observed in the Cottage cheese packaged in the atmosphere containing/not containing $\mathrm{CO}_{2}$. They concluded that the lack of growth in $C$. sporogenes was possibly associated with the effect of suboptimal $\mathrm{pH}$ and temperature in the combination action, not with the $\mathrm{CO}_{2}$ influence.

\subsection{Sensory evaluation}

\subsubsection{Color}

HunterLab is the most common equipment used to monitor the color (Hunter $L^{*}, a^{*}$, and $b^{*}$ ) values of cheese samples over the storage time. Temiz et al. (2009) reported 
that the highest $L^{*}$ value (lightness) and the greatest negative $a^{*}$ value (greenness), among all packaging treatments, belonged to the atmospheres consisting of $70 \%$ $\mathrm{CO}_{2} / 30 \% \mathrm{~N}_{2}$ and $40 \% \mathrm{CO}_{2} / 60 \% \mathrm{~N}_{2}$, respectively. The $b^{*}$ values (yellowness), despite a significant effect of storage time and packaging technique, remained unchanged between days 17 and 38 in the Turkish whey cheese.

However, Maniar et al. (1994) showed no changes in the $L^{*}, a^{*}$, and $b^{*}$ values of Cottage cheeses stored at $4{ }^{\circ} \mathrm{C}$ for treatments (marked samples, packed samples in air, $100 \% \mathrm{CO}_{2}, 100 \% \mathrm{~N}_{2}$, and $75 \% \mathrm{CO}_{2} / 25 \% \mathrm{~N}_{2}$ ) and observed only minor differences, which were considered to be instrument-related noise and variations in sample presentation (Clydesdale 1969; Dixon and Kelly 1988). The findings by Favati et al. (2007) were in line with these results, in which the authors proposed that storage conditions (i.e., gas composition, storage duration, and storage temperature) were not able to have a significant influence on the color of Provolone cheese. However, regarding $b^{*}$ (yellowness), Del Nobile et al. (2009) noted significant differences between the Ricotta cheese stored under ordinary and modified atmospheres with the gas mixtures of $50 \% \mathrm{CO}_{2} / 50 \% \mathrm{~N}_{2}, 70 \% \mathrm{CO}_{2} / 30 \% \mathrm{~N}_{2}$, and $95 \% \mathrm{CO}_{2} / 5 \% \mathrm{~N}_{2}$. Esmer et al. (2009) also indicated no significant effect of gaseous atmosphere of $20 \% \mathrm{CO}_{2} / 80 \% \mathrm{~N}_{2}$ on the $L^{*}, a^{*}$, and $b^{*}$ values of Crottin de Chavignol cheese stored at $4{ }^{\circ} \mathrm{C}$. Temiz (2010) observed the relative decline in color values $\left(L^{*}, a^{*}\right.$, and $\left.b^{*}\right)$ in Kashar cheese, but no statistical effect was recorded for MAP $\left(20 \%, 40 \%\right.$, and $\left.100 \% \mathrm{CO}_{2}\right)$ treatments. The best gas mixture, to limit the color deterioration, was found to be pure $\mathrm{CO}_{2}$ flushing, except for the $b^{*}$ value which received the worst and the highest score given to packaging under air atmosphere.

Trobetas et al. (2008) observed the gradual discoloration only in the Graviera hard cheese packed under MAP atmospheres $\left(100 \% \mathrm{CO}_{2}, 100 \% \mathrm{~N}_{2}\right.$, and $50 \% \mathrm{CO}_{2} / 50 \%$ $\mathrm{N}_{2}$ ) and exposed to light at $4{ }^{\circ} \mathrm{C}$. The changes in color were as follows: $L^{*}$ value decreased, which was related to carotenoid degradation induced by light, as an inner filter (Hansen and Skibsted 2000), and the riboflavin degradation, as a photosensitizer in the photo-oxidation reaction (Bosset et al. 1995). With regard to the $a^{*}$ and $b^{*}$ values, these experienced an increase and decrease, respectively, while the values of the samples stored in the dark remained constant. These observations agree with Juric et al. (2003) who found similar trends in the color values of semi-hard cheese (Samøs) packed in different gas mixtures $\left(100 \% \mathrm{CO}_{2}, 100 \% \mathrm{~N}_{2}\right.$, and $20 \%$ $\mathrm{CO}_{2} / 80 \% \mathrm{~N}_{2}$ ) for the first 4 days of storage. The authors also showed that the packaged cheese flushed with pure $\mathrm{CO}_{2}$ under the light was darker in comparison with the samples in atmospheres with/without $20 \% \mathrm{CO}_{2}$ stored in the dark, perhaps due to the drying effect of $\mathrm{CO}_{2}$ and light exposure.

However, Kristensen et al. (2000) reported no significant differences in $L^{*}$ and $b^{*}$ values between Havarti cheese packed in $25 \% \mathrm{CO}_{2} / 75 \% \mathrm{~N}_{2}$ stored either under the light or in the dark at $4{ }^{\circ} \mathrm{C}$, although a trend of decreasing yellowness was notable in samples and an increase in $a^{*}$ values of samples was detected. Moreover, Colchin et al. (2001) observed that shredded cheddar cheeses packaged under pure $\mathrm{CO}_{2}$ and fluorescent light (1,000 lx), among treatment groups $\left(\mathrm{CO}_{2}+\right.$ light, $\mathrm{CO}_{2}+$ dark, $\mathrm{N}_{2}+$ light, and $\mathrm{N}_{2}+$ dark $)$, exhibited significantly higher $L^{*}$ values, whereas the $a^{*}$ and $b^{*}$ values detected were considerably lower. On the other hand, the shredded cheese color shifted from the traditional 
orange color to a definite white hue. Light intensity is well known to be fatal to the color stability of stored cheese, which should be taken into consideration while designing MAP by paying attention to the fact that light intensities $\geq 1,614$ lx may help cheese color fade (Deger and Ashoor 1987; Hong et al. 1995).

\subsubsection{Odor and taste}

The lowest acceptability score for odor and taste is 3.5 [0-5 point scale (where a score of 4-5 corresponds to quality class I, no off-flavor), 3.5-3.99 corresponds to class II (initial off-flavor but not spoiled), and a score 3.5 corresponds to quality class III (spoiled sample unfit for human consumption)] (Papaioannou et al. 2007) or 4.0 [a 9-point scale (where a score of 9 corresponds to extremely good, 8 very good, 7 quite good, 6 moderately good, 5 neither good nor bad, 4 moderately bad, 3 quite bad, 2 very bad, and 1 extremely bad)] (Temiz et al. 2009). The majority of studies reported the effectiveness of MAP in prolonging the sensory acceptability of cheeses in terms of taste and odor (Maniar et al. 1994: $\geq 75 \% \mathrm{CO}_{2}$ for taste; Papaioannou et al. 2007: $70 \% \mathrm{CO}_{2} / 30 \% \mathrm{~N}_{2}$ for both odor and taste; Dermiki et al. 2008: $60 \% \mathrm{CO}_{2} / 40 \% \mathrm{~N}_{2}$ for both odor and taste; Temiz et al. 2009: $40 \% \mathrm{CO}_{2} / 60 \% \mathrm{~N}_{2}$ and $70 \% \mathrm{CO}_{2} / 30 \% \mathrm{~N}_{2}$ for odor and taste; Temiz 2010: $40 \% \mathrm{CO}_{2} / 60 \% \mathrm{~N}_{2}$ and $100 \% \mathrm{CO}_{2}$ for taste as an effective gas mixture for Cottage cheese, Greek whey cheese, whey cheese, Turkish whey cheese, and Kashar cheese, respectively).

Although Gonzalez-Fandos et al. (2000) demonstrated that the atmosphere containing $100 \% \mathrm{CO}_{2}$ had a very negative effect on the sensory quality of Cameros cheese, the worst scores for taste were obtained in pure $\mathrm{CO}_{2}$-packaged cheeses, and panelists rejected them after 14 days of storage. Similarly, Garabal et al. (2010) showed that vacuum packaging is the best method for retaining the sensory quality of San Simón da Costa smoked semi-hard cheeses.

Despite these results, Alves et al. (1996) and Maniar et al. (1994) reported that plain $\mathrm{CO}_{2}$ was the best at maintaining the sensorial characteristics of Mozzarella and Cottage cheeses, respectively. Mannheim and Soffer (1996), as well, showed that Cottage cheese samples do not suffer from packaging with $100 \% \mathrm{CO}_{2}$ with regard to the sensorial characteristics, and no changes in taste or even texture were recorded. However, Esmer et al. (2009) noted that the highest score was given to the Crottin de Charignol cheeses with a $20 \% \mathrm{CO}_{2} / 80 \% \mathrm{~N}_{2}$ gas composition.

\section{Conclusion}

Dairy products, especially cheese, are attractive and nutritional products. Therefore, keeping them fresh and extending their shelf life is important and favorable for both producers and consumers. Increased awareness of consumers from fresh and preservative-free food has led scientists to investigate new alternative approaches to the traditional preservation methods, one of which is to use the modified 
atmosphere packaging (MAP) as a technique for improving the product image and extending the shelf life of various foods.

The MAP technique was proven to be useful in prolonging the shelf life of cheese samples in terms of microbiological and sensorial aspects, in which the recommended gas mixtures depend on cheese type, cheese manufacturing conditions, initial microbial load of cheese, packaging materials, and storage circumstances, as well as post-processing activities.

\section{References}

Alam T, Goyal GK (2007) Influence of modified atmosphere packaging and storage at deep freeze conditions on the sensory characteristics of Mozzarella cheese. Milchwissenschaft 62(3):311-314

Alves RMV, De Luca S, Grigoli CI, Van Dender AGF, De Assis FF (1996) Stability of sliced Mozzarella cheese in modified-atmosphere packaging. J Food Prot 59(8):838-844

Awad S (2006) Texture and flavour development in Ras cheese made from raw and pasteurised milk. Food Chem 97(3):394-400

Bahk J, Marth EH (1990) Listeriosis and Listeria monocytogenes. Foodborne diseases. Academic, San Diego, pp 247-257

Belin JM (1990) Les levures. Chapter 2. In: Bourgeois CM, Mescle JF, Zucca J (eds) Aspect microbiologique de la sécurité et de la qualité alimentaires, Microbiologie alimentaire, 1st edn. Tec \& Doc, Lavoisier, Paris, pp 161-173

Bellengier P, Foucaud C, Hemme D (1993) Carbon dioxide production from citrate and glucose in Leuconostoc species determined by an adapted enzymatic method. Milchwissenschaft 48(10):548551

Bille J (1990) Epidemiology of human listeriosis in Europe with special reference to the Swiss outbreak. In: Miller AJ, Smith JL, Somkuti GA (eds) Foodborne listeriosis. Elsevier, Amsterdam, pp 71-74

Bosset JO, Sieber R, Gallmann PU (1995) Light transmittance: influence on the shelf life of milk and milk products. Bull Int Dairy Fed 300:19-39

Brody AL (1989) Controlled/modified atmosphere/vacuum packaging of foods. Food and Nutrition Press, Trumbull

Chen JH, Hotchkiss JH (1991) Effect of dissolved carbon dioxide on the growth of psychrotrophic organisms in Cottage cheese. J Dairy Sci 74(9):2941-2945

Church N (1994) Developments in modified-atmosphere packaging and related technologies. Trends Food Sci Technol 5(11):345-352

Clydesdale FM (1969) The measurement of color. Food Technol 23(1):16

Colchin LM, Owens SL, Lyubachevskaya G, Boyle-Roden E, Russek-Cohen E, Rankin SA (2001) Modified atmosphere packaged cheddar cheese shreds: influence of fluorescent light exposure and gas type on color and production of volatile compounds. J Agric Food Chem 49(5):2277-2282

Coppola R, Sorrentino E, Cinquanta L, Rossi F, Iorizzo M, Grazia L (1995) Shelf-life of Mozzarella cheese samples packaged without liquid and stored at different temperatures $=$ shelf-life di mozzarelle confezionate senza liquido di governo e conservate a differenti temperature. Italian J Food Sci 7 (4):351-359

Daniels JA, Krishnamurthi R, Rizvi SSH (1985) A review of effects of carbon dioxide on microbial growth and food quality. J Food Prot (USA) 48(6):532-537

Dankow R, Pikul JAN, Wojtowski J, Ska D (2006) Effect of packaging systems on the quality and shelflife of the Rokpol type mould cheese from goat milk. Arch Tierz Dummerstorf 49:214-218

Deger D, Ashoor SH (1987) Light-induced changes in taste, appearance, odor, and riboflavin content of cheese. J Dairy Sci 70(7):1371-1376

Del Nobile MA, Conte A, Incoronato AL, Panza O (2009) Modified atmosphere packaging to improve the microbial stability of Ricotta. African J Microbiol Res 3(4):137-142

Dermiki M, Ntzimani A, Badeka A, Savvaidis IN, Kontominas MG (2008) Shelf-life extension and quality attributes of the whey cheese. LWT Food Sci Technol 41(2):284-294

Dixon NM, Kelly DB (1988) The inhibition by CO2 of the growth and metabolism of microorganisms. J Appl Bacteriol 67:109 
Donnelly CW, Briggs EH (1986) Psychrotrophic growth and thermal inactivation of Listeria monocytogenes as a function of milk composition. J Food Prot 49(12):994-998

Eliot SC, Vuillemard JC, Emond JP (1998) Stability of shredded Mozzarella cheese under modified atmospheres. J Food Sci 63(6):1075-1080

Esmer OK, Balkir P, Seckin AK, Irkin R (2009) The effect of modified atmosphere and vacuum packaging on the physicochemical, microbiological, sensory and textural properties of Crottin de Chavignol cheese. Food Sci Technol Res 15(4):367-376

Farber JM (1991) Microbiological aspects of modified-atmosphere packaging technology-a review. J Food Prot 54(1):58-70

Farber JN, Harris LJ, Parish ME, Beuchat LR, Suslow TV, Gorney JR, Garrett EH, Busta FF (2003) Microbiological safety of controlled and modified atmosphere packaging of fresh and fresh cut produce. Compr Rev Food Sci Food Safety 2:142-160

Favati F, Galgano F, Pace AM (2007) Shelf-life evaluation of portioned Provolone cheese packaged in protective atmosphere. LWT Food Sci Technol 40(3):480-488

Fedio WM, Macleod A, Ozimek L (1994) The effect of modified atmosphere packaging on the growth of microorganisms in Cottage cheese. Milchwissenschaft 49(11):622-629

Floros JD, Nielsen PV (2000) Advances in modified atmosphere and active packaging with applications in the dairy industry. Packaging milk prod 346:22-28

Gammariello D, Conte A, Attanasio M, Del Nobile MA (2009a) Effect of modified atmospheres on microbiological and sensorial properties of Apulian fresh cheeses. African J Microbiol Res 3(7):370378

Gammariello D, Conte A, Di Giulio S, Attanasio M, Del Nobile MA (2009b) Shelf life of Stracciatella cheese under modified-atmosphere packaging. J Dairy Sci 92(2):483-490

Garabal JI, Rodríguez-Alonso P, Franco D, Centeno JA (2010) Chemical and biochemical study of industrially produced San Simón da Costa smoked semi-hard cow's milk cheeses: effects of storage under vacuum and different modified atmospheres. J Dairy Sci 93(5):1868-1881

Genigeorgis C, Carniciu M, Dutulescu D, Farver TB (1991) Growth and survival of Listeria monocytogenes in market cheeses stored at 4 to $30^{\circ} \mathrm{C}$. J Food Prot (USA) 54:662-668

Georgala A, Moschopoulou E, Aktypis A, Massouras T, Zoidou E, Kandarakis I, Anifantakis E (2005) Evolution of lipolysis during the ripening of traditional Feta cheese. Food Chem 93(1):73-80

Gonzalez-Fandos E, Sanz S, Olarte C (2000) Microbiological, physicochemical and sensory characteristics of Cameros cheese packaged under modified atmospheres. Food Microbiol 17 (4):407-414

Guler Z (2005) Quantification of free fatty acids and flavor characteristics of Kashar cheeses. J Food Lipids 12:209-221

Guynot ME, Marín S, Sanchis V, Ramos AJ (2004) An attempt to minimize potassium sorbate concentration in sponge cakes by modified atmosphere packaging combination to prevent fungal spoilage. Food Microbiol 21(4):449-457

Han JH (2005) New technologies in food packaging: overview. In: Han JH (ed) Innovations in food packaging. Academic, London, pp 3-11

Hansen E, Skibsted LH (2000) Light-induced oxidative changes in a model dairy spread. Wavelength dependence of quantum yields. J Agric Food Chem 48(8):3090-3094

Hong CM, Wendorff WL, Bradley RL Jr (1995) Effects of packaging and lighting on pink discoloration and lipid oxidation of annatto-colored cheeses. J Dairy Sci 78(9):1896-1902

Hotchkiss JH (1988) Experimental approaches to determining the safety of food packaged in modified atmospheres. Food Technol 42(9):55-64

ICMSF (1978) Microorganisms in foods. 1. Their significance and methods of enumeration. International Commission on Microbiological Specifications for Foods, 2nd edn. University of Toronto Press, Toronto

IDF (1989) Milkfat products and butter, determination of fat acidity. International Dairy Federation Standard 6b, Brussels, IDF

James SM, Fannin SL, Agee BA, Hall B, Parker E, Vogt J, Run G, Williams J, Lieb L, Salminen C (1985) Listeriosis outbreak associated with Mexican-style cheese-California. Morbid Mortal Weekly Rep 34 (24):357-359

Jayas DS, Jeyamkondan S (2002) PH-postharvest technology: modified atmosphere storage of grains meats fruits and vegetables. Biosystems Eng 82(3):235-251

Juric M, Bertelsen G, Mortensen G, Petersen MA (2003) Light-induced colour and aroma changes in sliced, modified atmosphere packaged semi-hard cheeses. Int Dairy J 13(2-3):239-249 
King AD Jr, Nagel CW (1967) Growth inhibition of a Pseudomonas by carbon dioxide. J Food Sci 32 (5):575-579

Kosikowski FV, Brown DP (1973) Influence of carbon dioxide and nitrogen on microbial populations and shelf life of Cottage cheese and sour cream. J Dairy Sci 56(1):12-18

Koskeli M (1998) Cheese packaging. Scand Dairy Industry 1(88):19-20

Krcal Z (1970) New methods of storage of quarg intended as raw material for olmuzer quargel manufacture. Proceedings of the 18th International Dairy Congress

Kristensen D, Orlien V, Mortensen G, Brockhoff P, Skibsted LH (2000) Light-induced oxidation in sliced Havarti cheese packaged in modified atmosphere. Int Dairy J 10:95-103

Lee BH, Laleye LC, Simard RE, Munsch MH, Holley RA (1990) Influence of homofermentative lactobacilli on the microflora and soluble nitrogen components in cheddar cheese. J Food Sci 55 (2):391-397

Linnan MJL, Mascola L, Lou XD (1988) Epidemic listeriosis associated with eating Mexican-style cheese. New Engl J Med 319:823-828

Lioliou K, Litopoulou-Tzanetaki E, Tzanetakis N, Robinson RK (2001) Changes in the microflora of Manovri, a traditional Greek wheycheese, during storage. Int J Dairy Technol 54:100-106

Maniar AB, Marcy JE, Bishop JR, Duncan SE (1994) Modified atmosphere packaging to maintain direct set Cottage cheese quality. J Food Sci 59(6):1305-1308

Mannheim CH, Soffer T (1996) Shelf-life extension of Cottage cheese by modified atmosphere packaging. Lebensmittel Wissenschaft und-Technol 29(8):767-771

McMillin KW (2008) Where is MAP going? A review and future potential of modified atmosphere packaging for meat. A review. Meat Sci 80:43-65

Moir CJ, Eyles MJ, Davey JA (1993) Inhibition of Pseudomonads in Cottage cheese by packaging in atmospheres containing carbon dioxide. Food Microbiol 10(4):345-351

Mortensen G, Sørensen J, Stapelfeldt H (2003) Effect of modified atmosphere packaging and storage conditions on photooxidation of sliced Havarti cheese. Eur Food Res Technol 216(1):57-62

Mossel DAA, Corry JEL, Struijk CB, Baird RM, Brett M (1995) Essentials of the microbiology of foods. Wiley, Chichester

Mullan M, McDowell D (2003) Modified atmosphere packaging. In: Coles R, McDowell D, Kirwan MJ (eds) Food packaging technology. Blackwell, Oxford, pp 303-339

Nawar WW (1996) Lipids. In: Fennema OR (ed) Food chemistry, 4th edn. Marcel Dekker, New York, pp $139-245$

Olarte C, Gonzalez-Fandos E, Gimenez M, Sanz S, Portu J (2002) The growth of Listeria monocytogenes in fresh goat cheese (Cameros cheese) packaged under modified atmospheres. Food Microbiol 19 (1):75-82

Ooraikul B, Stiles ME (1991) Modified atmosphere packaging of food. Ellis Horwood Limited, Chichester

Papaioannou G, Chouliara I, Karatapanis AE, Kontominas MG, Savvaidis IN (2007) Shelf-life of a Greek whey cheese under modified atmosphere packaging. Int Dairy J 17(4):358-364

Phillips CA (1999) Modified atmosphere packaging and its effects on the microbiological quality and safety of produce. A review. Int J Food Sci Technol 31:463-479

Piergiovanni L, Fava P, Moro M (1993) Shelf-life extension of Taleggio cheese by modified atmosphere packaging. Italian J Food Sci 5:115-115

Pintado ME, Malcata FX (2000) Optimization of modified atmosphere packaging with respect to physicochemical characteristics of Requeijão. Food Res Int 33:821-832

Poveda JM, Pérez-Coello MS, Cabezas L (2000) Seasonal variations in the free fatty acid composition of Manchego cheese and changes during ripening. Eur Food Res Technol 210 (5):314-317

Prieto B, Franco I, Fresno JM, Bernardo A, Carballo J (2000) Picon Bejes-Tresviso blue cheese: an overall biochemical survey throughout the ripening process. Int Dairy J 10(3):159-167

Rodriguez-Aguilera R, Oliveira JC (2009) Review of design engineering methods and applications of active and modified atmosphere packaging systems. Food Eng Rev 1(1):66-83

Rodriguez-Aguilera R, Oliveira JC, Montanez JC, Mahajan PV (2011a) Effect of modified atmosphere packaging on quality factors and shelf-life of mould surface-ripened cheese: Part II varying storage temperature. LWT Food Sci Technol 44(1):337-342

Rodriguez-Aguilera R, Oliveira JC, Montanez JC, Mahajan PV (2011b) Effect of modified atmosphere packaging on quality factors and shelf-life of surface mould ripened cheese: Part I constant temperature. LWT Food Sci Technol 44:330-336 
Romani S, Sacchetti G, Pittia P, Pinnavaia GG, Dalla Rosa M (2002) Physical, chemical, textural and sensorial changes of portioned Parmigiano Reggiano cheese packed under different conditions. Food Sci Technol Int 8(4):203-211

Romani S, Sacchetti G, Vannini L, Pinnavaia GG, Dalla Rosa M, Corradini C (1999) Storage stability of portioned packed Parmigiano Reggiano cheese [Emilia-Romagna]; Stabilita'in conservazione del Parmigiano Reggiano confezionato in porzioni [Emilia-Romagna]. Scienza e Tecnica Lattiero Casearia (Italy) 50:273-290

Sandhya (2010) Modified atmosphere packaging of fresh produce: current status and future needs. A review. LWT Food Sci Technol 43:381-392

Scott CR, Smith HO (1971) Cottage cheese shelf life and special gas atmospheres. J Food Sci 36(1):78-80

Sendra E, Mor-Mur M, Plà R, Capellas M, Trujillo A, Guamis B (1994) Envasado de queso fresco en atmosferas modificadas $=$ Modified atmosphere packaging of semi-industrially fresh cheese from goat's milk. Alimentaria 250:33-38

Silva AS, Hernández JL, Losada PP (2004) Modified atmosphere packaging and temperature effect on potato crisps oxidation during storage. Anal Chimica Acta 524:185-189

Sousa MJ, McSweeney PLH (2001) Studies on the ripening of Cooleney, and Irish farmhouse Camemberttype cheese. Irish J Agric Food Res 40:84-95

Taniwaki MH, Hocking AD, Pitt JI, Fleet GH (2001) Growth of fungi and mycotoxin production on cheese under modified atmospheres. Int J Food Microbiol 68:125-133

Taylor BW, Harper WJ, Blaisdell JL (1965) Effects of packaging closure on keeping quality of Cottage cheese. J Dairy Sci 48:785

Temiz H (2010) Effect of modified atmosphere packaging on characteristics of sliced Kashar cheese. J Food Proc and Pres 34(5):926-943

Temiz H, Aykut U, Hursit AK (2009) Shelf life of Turkish whey cheese (Lor) under modified atmosphere packaging. Int J Dairy Technol 62(3):378-386

Trobetas A, Badeka A, Kontominas MG (2008) Light-induced changes in grated Graviera hard cheese packaged under modified atmospheres. Int Dairy J 18(12):1133-1139

Tsantilis CN, Kosikowski FV (1960) The keeping quality of Cottage cheese packaged under high vacuum, nitrogen and carbon dioxide. J Dairy Sci 43:846

Ucuncu M (2007) Gıdaların modifiye atmosferde ambalajlanmasi. In: Ucuncu M (ed) Gıda Ambalajlama Teknolojisi. Meta Basım Matbaacilık Hizmetleri, İzmir, pp 733-788

Whitley E, Muir D, Waites WM (2000) The growth of Listeria monocytogenes in cheese packed under a modified atmosphere. J Appl Microbiol 88(1):52-57

Zardetto S (2005) Effect of modified atmosphere packaging at abuse temperature on the growth of Penicillium aurantiogriseum isolated from fresh filled pasta. Food Microbiol 22(4):367-371

Zimmerman MK, Kester LT (1960) A study of the surface spoilage defect of Cottage cheese. J Dairy Sci 43:845 